\title{
An empirical analysis of the non-linear impacts of ICT-trade openness on renewable energy transition, energy efficiency, clean cooking fuel access and environmental sustainability in South Asia
}

\author{
Muntasir Murshed ${ }^{1}$ (D) \\ Received: 12 March 2020 / Accepted: 28 May 2020 / Published online: 18 June 2020 \\ (C) Springer-Verlag GmbH Germany, part of Springer Nature 2020
}

\begin{abstract}
Energy security and environmental sustainability have become an integral policy agenda worldwide whereby the global economic growth policies are being restructured to ensure the reliability of energy supply and safeguard environmental well-being as well. However, technological inefficiency is one of the major hindrances in attaining these over-arching goals. Hence, this paper probed into the non-linear impacts of ICT trade on the prospects of undergoing renewable energy transition, improving energy use efficiencies, enhancing access to cleaner cooking fuels, and mitigating carbon dioxide emissions across selected South Asian economies: Bangladesh, India, Pakistan, Sri Lanka, Nepal, and Maldives. The results from the econometric analyses reveal that ICT trade directly increases renewable energy consumption, enhances renewable energy shares, reduces intensity of energy use, facilitates adoption of cleaner cooking fuels, and reduces carbon-dioxide emissions. Moreover, ICT trade also indirectly mitigates carbon-dioxide emissions through boosting renewable energy consumption levels, improving energy efficiencies, and enhancing cleaner cooking fuel access. Hence, these results, in a nutshell, portray the significance of reducing the barriers to ICT trade with respect to ensuring energy security and environmental sustainability across South Asia. Therefore, it is ideal for the government to gradually lessen the trade barriers to boost the volumes of cross-border flows of green ICT commodities. Besides, it is also recommended to attract foreign direct investments for the potential development of the respective ICT sectors of the South Asian economies.
\end{abstract}

Keywords ICT trade $\cdot$ Renewable energy transition $\cdot$ Energy efficiency $\cdot$ Cleaner cooking fuels $\cdot \mathrm{CO}_{2}$ emissions $\cdot$ Energy security . Environmental sustainability

JEL classifications $\mathrm{O} 13 \cdot \mathrm{O} 14 \cdot \mathrm{P} 28 \cdot \mathrm{Q} 2 \cdot \mathrm{Q} 42$

\section{Introduction}

The conventional reliance on use of the environmentally unfriendly non-renewable energy (NRE) resources to meet the world energy demand has eventually evoked consensus among the global economies for attaining both socioeconomic and environmental sustainability, particularly through optimal utilization of the relatively cleaner renewable energy (RE) alternatives. The monotonic dependency on the combustion

Responsible editor: Nicholas Apergis

Muntasir Murshed

muntasir.murshed@northsouth.edu

1 School of Business and Economics, North South University, Dhaka, Bangladesh of the NRE resources has attributed to over-exploitation of these finite resources, thus, jeopardizing the global energy security phenomena to a large extent (Murshed and Tanha 2020). Besides, insufficient supply of the primary NRE resources has also compromised the reliability of the secondary energy supplies, electricity, in particular, obliging the global power plants to operate below their respective installed capacities (Xue et al. 2014). Simultaneously, a persistent surge in the world demand for energy has aggravated the global energy crises further (Smil and Knowland 1980). Amidst such energy supply crunch, energy planners often prescribe supply-side management of energy employment through augmentation of RE resources into the national energy-mix (Kumar et al. 2010) while enhancing the efficiency of energy use as a demand-side management mechanism in this regard (Yang and $\mathrm{Yu}$ 2015). 
Apart from marginalizing the prospects of establishing energy security within the economy, the predominant consumption of the NRE resources is also alleged to have induced environmental deterioration globally. Combustion of these non-renewable fossil fuels has exacerbated emissions of greenhouse gases into the atmosphere, thus, attributing to the climate change adversities across the global domain (Saboori and Sulaiman 2013). Consequently, undergoing renewable energy transition ${ }^{1}$ (RET) is thought to be a credible means to curbing the environmental pollutants discharged from the combustion of the NRE resources (Sharif et al. 2020). Widespread employment of RE resources has been linked to de-carbonization of the global economy (Rockström et al. 2017) whereby switching from the fossil fuel to $\mathrm{RE}$ consumption can mitigate carbon-dioxide $\left(\mathrm{CO}_{2}\right)$ emissions, the major greenhouse gas responsible for instigating the climate change hardships. Therefore, it can be hypothesized RET is more of a pre-requisite to achieving both energy security and environmental sustainability across the world.

The key roles of RET with respect to mitigating global energy crises and enhancing environmental quality have also been highlighted in the Sustainable Development Goals (SDG) declaration of the United Nations (UN). The 7th goal, out of the seventeen SDG, precisely calls out for global commitments for elevating the access to affordable, reliable, sustainable, and modern supplies worldwide by substantially elevating the shares of renewables in the total final energy consumption levels across the globe while doubling the energy use efficiency levels by $2030 .^{2}$ However, undergoing RET is not a walk in the park, especially in the context of the underdeveloped economies. The technological constraints faced by the developing nations is one of the central reasons bottlenecking the prospects of RET within these economies (Nguyen and Kakinaka 2019). Technological redundancy is said to impede the adoption of RE technologies across the low-income economies in particular (Fashina et al. 2019). Similarly, Lu et al. (2020) argued that technological backwardness hampers the storage of energy generated from renewable sources whereby incorporation of RE into the energy mix becomes a cumbersome task. As a result, lack of technical know-how has restrained the development of the weak energy infrastructures of the developing economies which, in turn, delayed the process of non-renewable to renewable transition in energy use within these economies (Edomah 2016). Hence, it is pertinent to identify the factors that can effectively overcome these technological barriers obstructing RET, particularly across the third world countries.

Under such circumstances, trade of Information and Communications Technology (ICT) goods and services can

\footnotetext{
${ }^{1}$ For an in-depth understanding of the RET phenomenon see Murshed (2018).

${ }^{2}$ For further information on goal 7 of the UN's Sustainable Development Goals see https://sustainabledevelopment.un.org/sdg7
}

portray fundamental roles for uplifting the technological constraints and facilitating the RET phenomenon, in tandem. In the context of countries with low technological progress, the import of ICT commodities is believed to facilitate the development of the ICT sectors of the importing nations (Nath and Liu 2017). Now, with respect to promoting the consumption of RE in the economy, the application of ICT is hypothesized to account for the variable supplies of the primary sources of RE. The availability of these resources is conditional in nature whereby one simply cannot expect an uninterrupted supply of these resources throughout the day or all-round the year. Thus, the application of ICT, in this regard, could be ideal in ensuring maximum harvest of the RE resources, during their respective peak availability periods, and also facilitate the storage of the electricity generated from these RE resources (Ahmed et al. 2017). Hence, such ICT-enabled energy infrastructure development is often claimed to be overcome the limitations that have traditionally obstructed the RET phenomenon within the developing countries in particular. Besides, ICT innovation is also linked to a reduction in the levelized costs of renewable electricity generation (Lai et al. 2017; Murshed and Tanha 2020) which, in turn, is likely to enhance the shares of renewables in the aggregate electricity output levels.

On the other hand, keeping into cognizance the issue of energy security, from the demand-side channels, ICT can also be tapped to enhance the efficiency of energy use by identification of the sources of irregularities within the conventional power grids, that too in near-real-time (Schulte et al. 2016). Thus, smartening of the old-fashioned malfunctioning grids through the implementation of ICT could be a remedy to the high degrees of system losses (or energy wastages) that are accounted due to the predominant technical inefficiencies engulfing the traditional power gridding systems across the globe (World Energy Council 2018; Murshed 2020b). Also, ICT can complement the energy conservation strategies for optimizing energy employment within buildings. Therefore, ICT can be expected to further reduce the intensity of energy use among both the commercial and residential end-users (Pasichnyi et al. 2019). Integration of ICT into the global energy sector was predicted to 3.5 to $6.3 \%$ reduction in the global energy use intensities by the end of 2020 (Rodríguez Casal et al. 2005) ${ }^{3}$.In addition, ICT-induced RET can also be presumed to impose favorable outcomes concerning energy efficiency improvements due to the RE resources, in comparison to the NRE resources, being more energy-intensive in nature. However, although ICT is expected to elevate the energy use efficiencies, the rebound energy consumption effects associated with ICT use cannot be overlooked whereby higher efficiency of energy use could trigger greater demand for

\footnotetext{
${ }^{3}$ This prediction was made without considering the impacts of the Covid-19 pandemic which resulted in a significant drop in the world demand for energy.
} 
energy (Walzberg et al. 2020). Under such an adverse scenario, the energy conservation and security goals behind the liberalization of the ICT trade barriers could be jeopardized.

Simultaneously, the development of the ICT sector is also envisioned to endorse environmental welfare, particularly through the mitigation of $\mathrm{CO}_{2}$ and other greenhouse emissions (Walzberg et al. 2020). The literature on the impacts of ICT on $\mathrm{CO}_{2}$ emissions has documented ambiguous findings. For instance, ICT use is said to accentuate the demand for electricity which, in turn, can be linked to higher energy consumption and greater emission of $\mathrm{CO}_{2}$ (Moyer and Hughes 2012). In contrast, other studies have referred to the greening of the ICT sector to attribute to lower $\mathrm{CO}_{2}$ emissions (Suryawanshi and Narkhede 2020). On the other hand, the nexus between ICT use and $\mathrm{CO}_{2}$ emissions could also depict an inverted-Ushaped relationship implicating that the positive impacts of ICT development on environmental quality are subject to time lags (Faisal et al. 2020). Furthermore, despite the consumption of ICT goods and services being argued to directly aggravate the $\mathrm{CO}_{2}$ emissions into the atmosphere, the impacts can indirectly be reversed through ICT-enabled enhancement of energy use efficiencies and greening of the ICT sector (Avom et al. 2020). Moreover, the application of ICT also functions as a means of replacing the traditional environmentally unfriendly cooking fuels by the relatively environmentally friendly cleaner substitutes (Schunder and Bagchi-Sen 2019; Acharya and Marhold 2019). Such a transition to the cleaner cooking fuels would also lay significant roles in reducing $\mathrm{CO}_{2}$ emission to further attribute to environmental betterment. Hence, it is apparent that the impacts of ICT use on RET, energy efficiency improvement, and reduction of $\mathrm{CO}_{2}$ emissions are inter-linked which justifies the pertinence of examining these overarching associations for unearthing critically important policy implications.

Against this backdrop, this paper makes a novel attempt to evaluate the impacts of liberalizing barriers to trade of ICT commodities on the prospects of undergoing RET, amplifying efficiency of energy use, enhancing access to cleaner cooking fuels, and mitigating $\mathrm{CO}_{2}$ emissions in the context of selected South Asian economies: Bangladesh, India, Pakistan, Sri Lanka, Nepal, and Maldives. ${ }^{4}$ The paper uses annual data from 2000 to 2016 and contributes to the literature in several ways. Firstly, it specifically analyzes the impacts of increasing openness to ICT trade for facilitating RET, energy use efficiency, clean cooking fuel access, and lower $\mathrm{CO}_{2}$ emissions for ensuring energy security and environmental sustainability across the concerned South Asian nation. Although a wide pool of preceding studies has probed into the impacts of the use of ICT products, like mobile services, Internet use, and fixed broadband subscriptions, in this regard, the corresponding impacts of liberalizing the trade barriers that uphold the

\footnotetext{
${ }^{4}$ The selection of the South Asian economies was based on data availability.
}

cross-border flows of ICT goods and services are yet to be documented in the literature. Secondly, to the best of knowledge, this is the first study that addresses the aforementioned roles of ICT trade in the context of South Asia. Thirdly, the potential non-linear nexus between ICT-trade openness and the aforementioned indicators of energy and environmental sustainability is explored.

The following questions are typically addressed in this paper:

1. Does higher ICT-trade openness facilitate the RET phenomenon in South Asia?

2. Can trade of ICT be linked to higher efficiency of energy use?

3. Does ICT trade induce switching from traditional cooking fuels to the relatively cleaner substitutes?

4. Does ICT trade improve environmental quality by lowering $\mathrm{CO}_{2}$ emissions?

The rest of the paper is organized as follows. "Stylized facts on ICT trade, energy consumption, and $\mathrm{CO} 2$ emission trends in South Asia" section provides a trend analysis of ICT trade across the selected South Asian economies and sheds light on the relevant energy consumption and environmental indicators as well. The existing literature in this regard is critically reviewed in "Literature study"section. "Model specification and data" section explains the econometric models and describes the attributes of the data set used in the analyses. The methodology of research is highlighted in "Methodology"section. "Results and discussion" section reports and discusses the findings from the econometric analyses while "Conclusion"section puts forward the concluding remarks.

\section{Stylized facts on ICT trade, energy consumption, and $\mathrm{CO}_{2}$ emission trends in South Asia}

Figure 1 illustrates the trends in ICT goods traded across the selected South Asian economies between 2000 and 2015. The fitted lines denote the average trends in the percentage shares of total imports and exports of ICT goods in the respective GDP, referred to as the ICT-trade openness indices, of all the six South Asian countries. Based on the projections, it is apparent that the ICT-trade openness indices of Bangladesh, India, and Nepal have, on average, increased while that of Pakistan, Sri Lanka, and the Maldives exhibited declining trends. In comparison between these nations, the ICT-trade openness indices of Maldives depicted a great deal of volatility over the 2000-2015 period. The mean value of the ICTtrade openness indices of Bangladesh, India, Pakistan, Sri Lanka, Maldives, and Nepal were $0.77 \%, 1.47 \%, 0.95 \%$, 


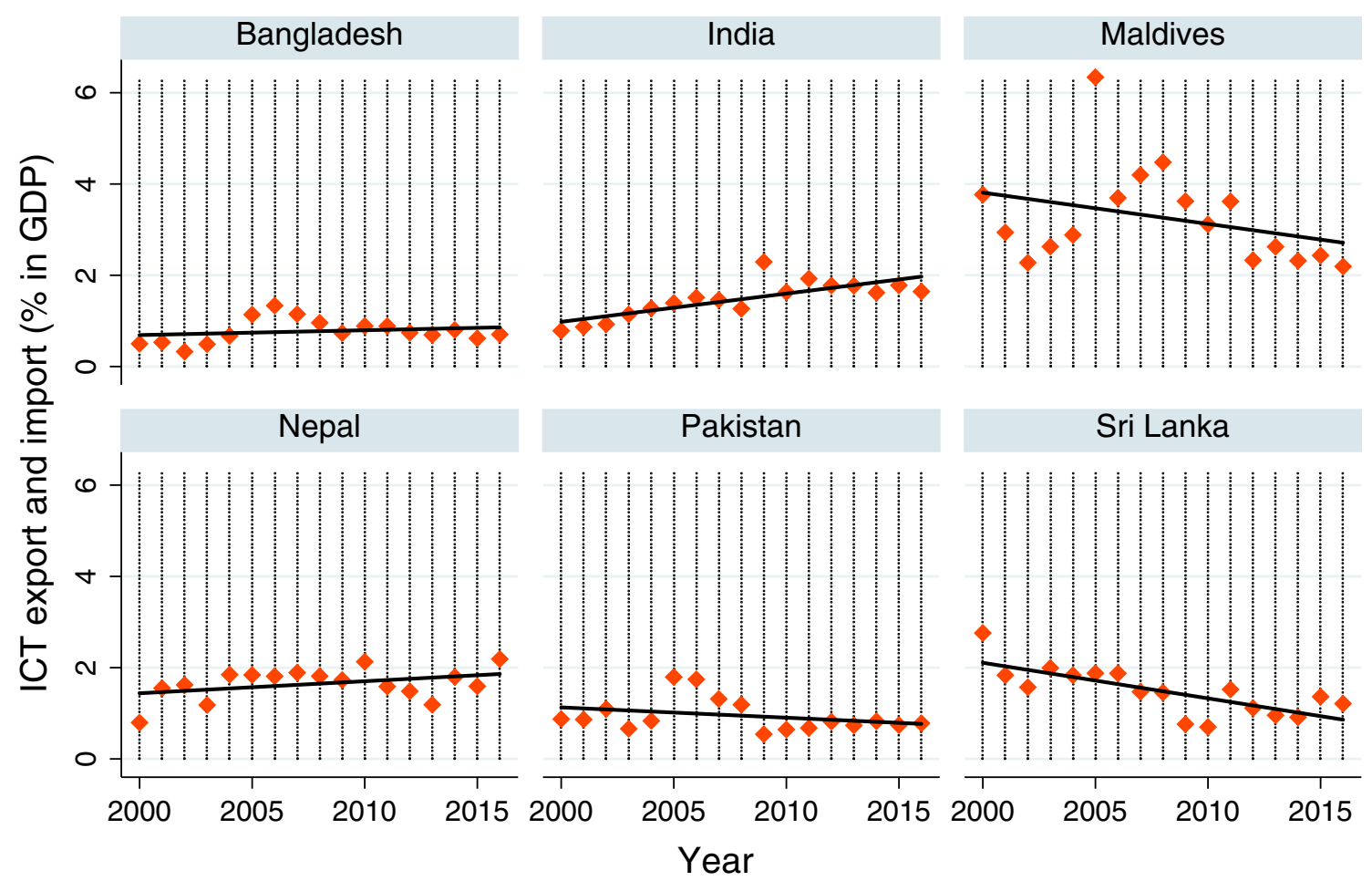

Fig. 1 ICT goods trade across South Asia (2000-2015)

$1.49 \%, 3.27 \%$, and $1.65 \%$, respectively, thus, portraying a great deal of heterogeneity in the states of ICT-trade openness across these nations. However, a common feature of these countries is that all these six South Asian nations have traditionally been net-importers of ICT commodities which partially reflect the dismal state of technological innovation across South Asia. This is one of the reasons that is presumed to have bottlenecked the prospects of undergoing RET across most of the South Asian countries.

Table 1 reports the trends in the RE shares in aggregate final energy consumption figures across the concerned South Asian economies over the 2000-2016 period. The figures denote that Nepal has traditionally been the forerunner, among the six South Asian economies, registering the highest levels of RE shares. The nation's predominant reliance on the consumption of indigenous hydropower supplies can be attributed to such substantial RE shares in Nepal (Agrawala et al. 2003).

Table 1 The renewable energy share in total final energy consumption (2000-2016)

\begin{tabular}{lllllll}
\hline Year & India & Bangladesh & Nepal & Pakistan & $\begin{array}{l}\text { Sri } \\
\text { Lanka }\end{array}$ & Maldives \\
\hline 2000-2004 & 50.90 & 54.78 & 89.14 & 50.12 & 62.42 & 1.86 \\
$2005-2008$ & 46.38 & 48.19 & 90.64 & 46.07 & 61.00 & 1.49 \\
$2009-2012$ & 39.39 & 40.70 & 86.97 & 46.27 & 61.32 & 1.15 \\
$2013-2016$ & 36.84 & 37.05 & 85.30 & 46.85 & 56.78 & 0.98 \\
\hline
\end{tabular}

Source: World Development Indicators (World Bank 2020)
In contrast, the RE shares in the aggregate final energy consumption figures of Maldives have been the lowest in the South Asian region. This can be attributed to the nation's monotonic dependency on petroleum imports for electricity generation purposes (van Alphen et al. 2007). A critically important thing to note from the statistical figures presented in Table 1 is that the RE shares in all the six South Asian nations have declined over the years; which contradicts with the RET commitments of these nations. Between 2000 and 2016, the RE shares in India, Bangladesh, Nepal, Pakistan, Sri Lanka, and the Maldives have declined by 14.06, 17.73, $3.84,3.27,5.64$, and 0.88 percentage points, respectively.

Figure 2 depicts the period average levels of energy use efficiency levels in terms of the intensities of energy employment within the South Asian economies. ${ }^{5}$ The figures reveal that Sri Lanka has been the most energy-efficient among the six South Asian economies considered in this paper which is evident from the nation's lowest level of intensity in comparison to that of the regional neighbors. Between 2000 and 2016, the energy use intensity in Sri Lanka had on average gone down by more than one-third of the level in 2000, thus, implicating a $37 \%$ rise in energy use efficiency gains. Conversely, Nepal has traditionally been regarded as the least energy efficient South Asian economy. A cumulative comparison reveals that all six nations have managed to improve their

\footnotetext{
${ }^{5}$ The reciprocal of the energy use intensity can be considered as the efficiency level of energy utilization in the economy. Hence, a decrease (or increase) in the intensity could be interpreted as an increase (or decrease) in the energy efficiency level.
} 


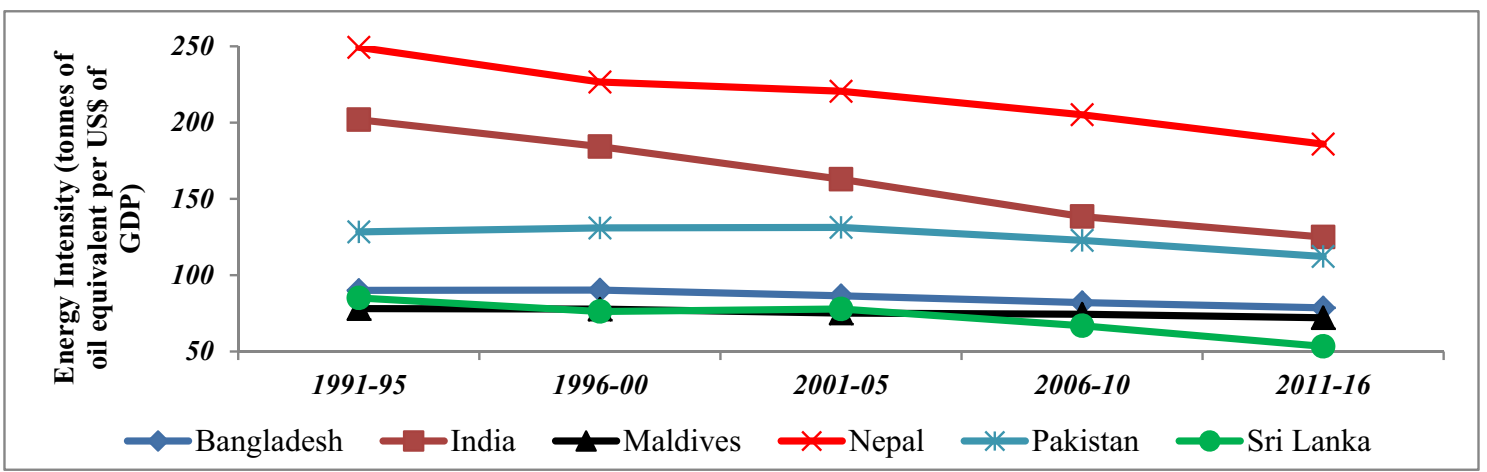

Fig. 2 Energy-use intensities in South Asia (1991-2016)

energy efficiency levels over the years. Sri Lanka has been the most successful nation in terms of enhancing its efficiency of energy use, registering almost $60 \%$ efficiency gain, on average, between 2000 and 2016. In contrast, India, Nepal, Bangladesh, Pakistan, and Maldives improved the energy efficiency levels by $39 \%, 37 \%, 12.71 \%, 12.53 \%$, and $7.66 \%$, respectively. Hence, these trends seem to portray a convergence in the energy efficiency levels among the South Asian countries.

The trends in the access to clean fuel and technologies (ACFT) for cooking purposes, among the respective population of the South Asian economies, are reported in Fig. 3. The line plots show that both India and Pakistan have succeeded in projecting identical trends in their respective ACFT for cooking levels while the corresponding trends in the context of Nepal and Sri Lanka have also overlapped for a considerable period of time between 2000 and 2016. On the other hand, Maldives has demonstrated significant improvement in elevating its ACFT for cooking figures, registering almost a three-fold increase over the aforementioned period. However, Bangladesh has been the least successful South Asian economy in terms of ensuring greater ACFT for cooking for its people. Between 2000 and 2016, the average ACFT for cooking in Bangladesh was merely $11.9 \%$, much lower than the rest of the South Asian neighbors.

Global $\mathrm{CO}_{2}$ emissions account for almost two-thirds of the aggregate greenhouse emissions, thus, labeling $\mathrm{CO} 2$ as the major attribute of environmental deterioration across the world (Field 2014; Jaffar et al. 2019). Figure 4 illustrates the $\mathrm{CO}_{2}$ emission trends across the selected South Asian economies. The line plots in the context of the carbon emission intensities show that India is the most polluted South Asian nation followed by Maldives and Pakistan. This implies that the production processes in all these three nations are intensive in the use of NRE resources which is also apparent in the corresponding RE consumption trends shown in Table 1. However, recently, both India and Pakistan have managed to reduce their carbon emission intensities which is not the case for the Maldives. In contrast, Bangladesh, Nepal, and Sri Lanka have fared fairly better performances in limiting their respective carbon emission intensities. However, it is to be noted that both the intensities of carbon emissions have, on average, gone up in Bangladesh and Nepal, but, in the case of Sri Lanka opposing trends can be witnessed. As far as the per capita $\mathrm{CO}_{2}$ emissions are concerned, Figure 4 shows that Bangladesh and Nepal have accounted for the lowest per capita $\mathrm{CO}_{2}$ emission figures among the selected South Asian economies. The low per capita $\mathrm{CO}_{2}$ emissions in Bangladesh can be accredited to the nation's predominant reliance on natural gas combustion for electricity generation purposes which, in comparison to the traditional oil-based power generation systems, emits comparatively lower volumes of $\mathrm{CO}_{2}$. On the other hand, Nepal's predominant reliance on RE consumption has possibly attributed to the nation's low per capita $\mathrm{CO}_{2}$ figures. Conversely, India despite being way more populated than the remaining five South Asian economies has accounted

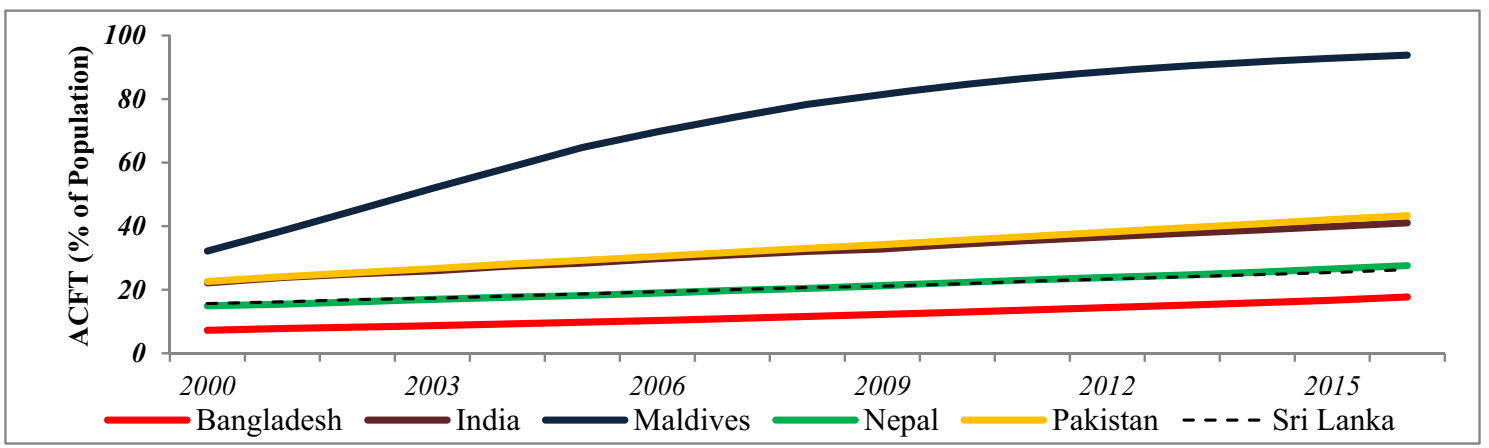

Fig. 3 ACFT for cooking trends in South Asia (2000-2016) 


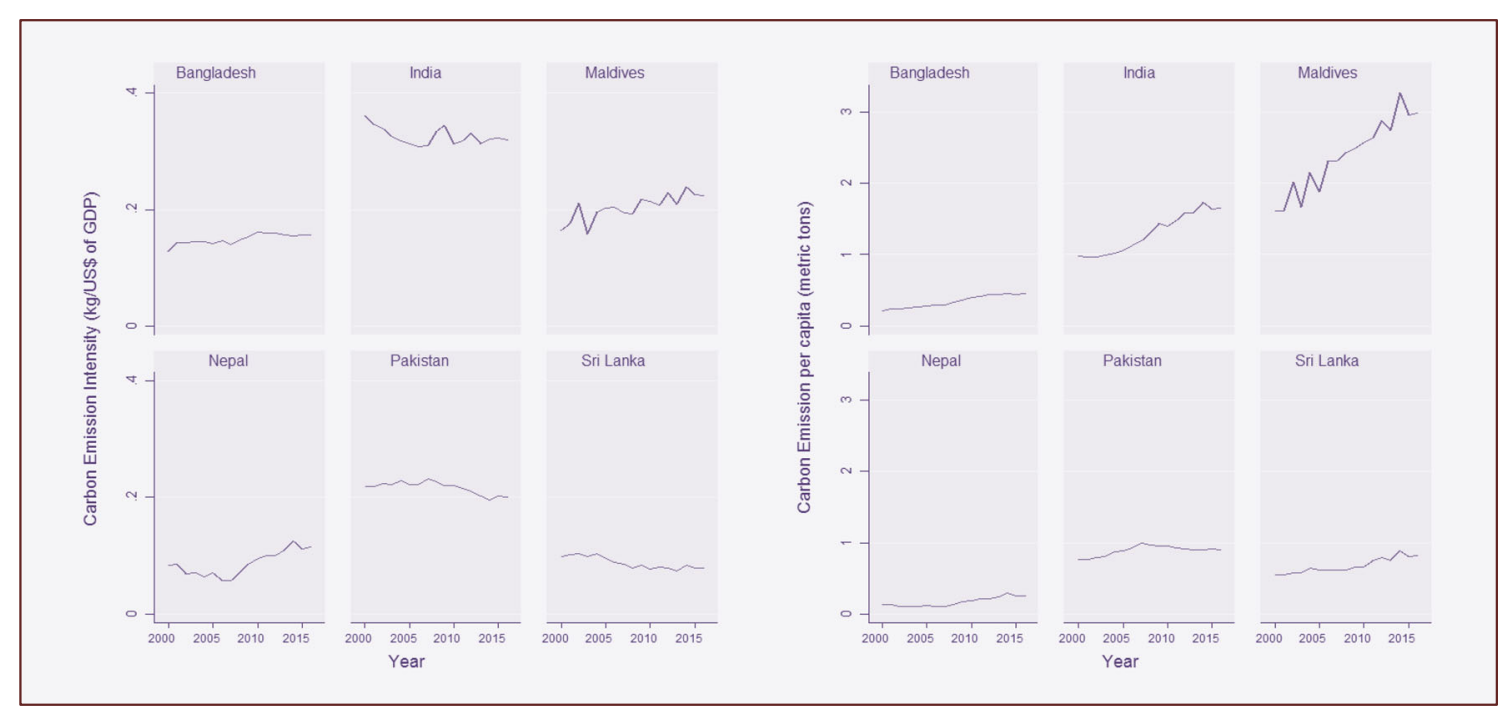

Fig. 4 Carbon dioxide emissions in South Asia (2000-2016)

for high and upward rising trends in its per capita $\mathrm{CO}_{2}$ levels between 2000 and 2016. The nation's surging energy demand stemming from rapid industrialization and unplanned urbanization is often claimed to be the core reason behind such high per capita $\mathrm{CO}_{2}$ emissions in India (Haider et al. 2019). Maldives is seen to be the topmost emitter of $\mathrm{CO}_{2}$ per capita in South Asia which can be attributed to the nation's high volumes of international trade due to the Maldives being the most open economy across South Asia (Afridi et al. 2019). In contrast, the per capita $\mathrm{CO}_{2}$ emission levels in Pakistan and Sri Lanka, almost converging in recent times, have been higher than Bangladesh and Nepal but lower than India and Maldives.

\section{Literature study}

\section{The theoretical framework on the ICT trade-RET-environmental sustainability nexus}

Acknowledgment of the capacities of ICT applications to employ RE resources leads to the notion of liberalizing barriers to ICT trade for promoting the overall volumes and shares of RE use within the trading economy. Reducing trade barriers, in general, is likely to facilitate cross-border flows of goods and services from a country that has a comparative advantage in producing them to a country having a relative disadvantage in this regard. This theory of international trade, postulated by Heckscher (1919) and Ohlin (1933), was later on extended by Vanek (1968) claiming that a particular country, having a comparative advantage in producing many commodities, would be a net exporter of only those products that intensively use the abundant factors locally available; while being a net importer of those products that intensively use the relative scarce indigenous factors of production. ${ }^{6}$ Likewise, mitigating barriers that impede the flows of ICT commodities across national boundaries would facilitate imports of ICT commodities into countries that are relatively less efficient in producing them using their own resources. This, in turn, can be anticipated to stimulate the incorporation of RE resources into the ICT imports, thus, ultimately promoting RE consumption within the ICT-importing nations. Moreover, ICT trade can also bridge the technological in-expertise across the developing economies, in particular, which had traditionally bottlenecked the prospects of undergoing RET within these economies (Murshed 2020a). This, in turn, could ideally ensure energy security within the economy whereby the RE resources are likely to complement the NRE resources in meeting the overall energy demand. Conversely, relaxing the barriers to ICT trade could also elevate the consumption of NRE resources by facilitating cross-border flows of dirty ICT products. Under such circumstances, the prospects of undergoing RET can be marginalized along with higher openness to ICT trade.

Apart from facilitating the policies aimed at undergoing RET, greater openness to ICT trade can also be expected to enhance environmental quality by reducing the $\mathrm{CO}_{2}$ emissions, both directly and indirectly. Under the direct channel, ICT can be tapped to identify the sources of $\mathrm{CO}_{2}$ emissions and can also be effective in designing exhausts for capturing the $\mathrm{CO}_{2}$ that would otherwise be emitted into the atmosphere (IEA 2017a, 2017b, November). On the other hand, ICT can indirectly exert positive impacts on the environment by facilitating RET which, in turn, would also attribute to lower $\mathrm{CO}_{2}$

\footnotetext{
${ }^{6}$ The claims made by Vanek (1968) are based on keeping the factor endowments across the exporting and importing nations into consideration.
} 
Fig. 5 The equivocal impacts of ICT trade on Environmental Quality

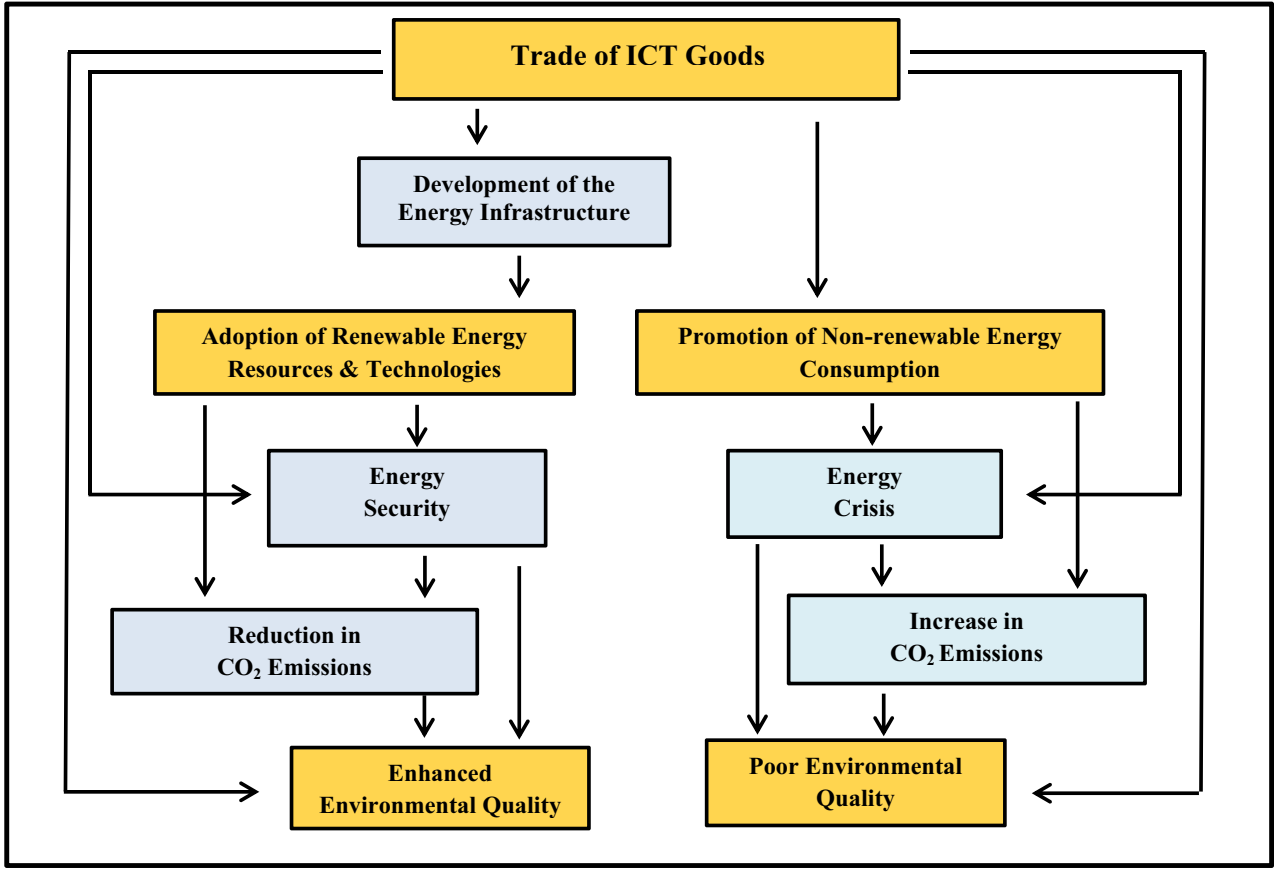

emissions due to the RE resources being environmentally friendly. In contrast, the trade of dirty ICT commodities that promotes the use of NRE resources can be expected to jeopardize environmental sustainability by escalating the volumes of $\mathrm{CO}_{2}$ emissions. This explains that the impacts of ICT-trade openness on environmental welfare are conditional on its impacts on NRE and RE energy consumptions. Figure 5, provides a flow chart indicating the ambiguous effects of ICTtrade liberalization policies on environmental quality.

\section{The literature on ICT and RET}

Although the pertinence of reducing the barriers hindering ICT trade flows has been theorized to be conducive to triggering the RET phenomenon, especially within the ICTimporting economies, the ICT trade openness-RET nexus is yet to be documented in the literature. However, several of the preceding studies did shed light on the impacts of trade openness, in general, on the RE use indicators. For instance, Omri and Nguyen (2014) referred to trade liberalization tools promoting greater consumption of RE resources across a panel of 64 high-, middle-, and low-income nations. In contrast, Zeren and Akkuş (2020) concluded in favor of trade openness being negatively and positively correlated with RE and NRE consumption, respectively, in the context of the top emerging economies. In a recent study encompassing 71 low- and middle-income global economies, Murshed (2020a) found empirical evidence of trade liberalization policies being aligned with the RET strategies only in the context of lowincome countries. Similarly, in a study comprising of five South Asian economies, Murshed (2018) concluded that mitigating barriers to trade was efficient in stimulating the RE consumption levels but it does not enhance the RE share in the aggregate energy consumption figures. Hence, visualizing ICT trade as a segment of total international trade, these aforementioned results concerning the in-general trade openness-RET nexus can somewhat reflect the possible dynamics that associate ICT trade liberalization policies to the RET phenomenon as well. However, evaluating the specific impacts of policies aimed at liberalizing the barriers to ICT trade on the prospects of elevating the RE consumption levels is key from policy perspectives, keeping energy security and environmental sustainability into cognizance. This paper aims to address the gap in the literature in this regard.

Although the specific impacts of openness to ICT trade on the RET phenomenon is yet to be scripted in the literature, a plethora of the existing studies have commented on the potential ways through which application of ICT can be beneficial to enhancing the RE use, thus, providing insightful justifications for relaxing the associated barriers impeding trade of the ICT commodities. The modern ICT applications are thought to be a direct medium for catalyzing the employment of RE resources (Andreopoulou 2012). Among the various manners through which ICT can promote RE use in the economy, ICT applications could be linked to smartening and greening of the conventional power grid whereby RE resources can be tapped to generate small-scale electric outputs (Ahmed et al. 2017). Similarly, Abid et al. (2017, September) claimed that ICTenabled smart grids promote the use of green energy resources via integration of the RE resources within the power generation processes. Such possibilities of off-grid renewable electrification were also highlighted by Alstone et al. (2015). 
Besides, Kostevšek et al. (2013) emphasized on the critically important roles of ICT in developing a RE-based network for developing the RE sector, thus, proactively meeting energy demands via the renewable sources of energy. Ekström et al. (2013) discussed the prospects of ICT in connecting electricity generated from tidal waves to the main grid. Furthermore, the authors particularly addressed the technological aspects through which inefficiencies within a hydropower plant can be identified with precision and in real-time.

The scopes for employing RE resources within the ICT sector in the USA were underlined in a report by Miller et al. (2015). The authors explicitly pointed out the ways through which the state could incentivize the ICT companies in employing renewable electricity to meet their respective demands for power, which is surging by the day. Similarly, Tsivor (2011, October) chalked down the potentials of introducing RE into the telecommunications and ICT sectors across the Sub-Saharan African nations. The author argued that a large segment of the population in the Sub-Saharan African nations do not have access to grid-electricity. Thus, provision for augmenting RE resources into the ICT sector, in particular, could effectively enhance the reliability of electricity supply, thus, portraying its key function in expanding the ICT sector further. Paul and Uhomoibhi (2014) referred to ICT being a pre-requisite to development of the solar power generation prospects across African economies which, in turn, was claimed to be a solution to the unreliable and insufficient electricity supply woes of these nations.

ICT is also believed to be a solution to the low rural electrification rates within the developing economies whereby employment of RE resources can ideally provide off-grid electricity access across the remote areas. In a study concerning the rural areas across emerging economies, Uhomoibhi and Paul (2012) claimed ICT to be effective in enhancing off-grid solar electricity access for the rural communities. Fadaeenejad et al. (2014) emphasized on the use of ICT to ensure transition from the use of fossil fuels to RE alternatives within the rural energy systems in Malaysia. Dhiman et al. (2019) identified ICT as a credible means of enhancing access to solar electricity amidst the rural population residing in the Northeastern states of India. Besides, Droege (2011) concluded that the application of ICT can promote production and supply of electricity from RE resources using wireless communications technologies especially across the rural areas. The ICT-rural off-grid electrification, employing renewable energy resources in particular, is of paramount importance for the South Asian. Palit and Bandhyopadhay (Palit and Bandyopadhyay 2016) inferred the renewable off-grid electricity supply to be the solution to low rural electrification problems of the South Asian economies.

Another notable aspect of ICT development for enhancing the overall use of RE could be understood in terms of the capacity of ICT to transform the energy consumer into becoming energy prosumers (Pasetti et al. 2018). Da Silva et al. (2013) stated that incorporation of RE into ICT-enable smart grids have the potential to curb individual energy consumption whereby the energy saved can be distributed within a group of end-users. Similar views were put forward by Vergados et al. (2016) in the context of Greece. The authors also asserted that ICT development can ensure precise forecasting of inefficiencies associated with consumption and production of energy which, in turn, would ideally reduce the costs associated with RE trading by the energy prosumers. On the other hand, Karnouskos (2011) underlined the methods through which technological innovation could facilitate interaction between prosumers, thus, enabling better demand-side management of energy use by smartening the conventional grid. Likewise, Weiller and Neely (2014) proposed how ICT can stimulate plug-in hybrid electric engines inside vehicles to employ relatively cleaner fuels to generate power which can be transmitted into the grid. Similar ICT-enabled vehicle-to-grid technology for integration of RE into the energy system in California was highlighted by Goebel and Callaway (2012).

However, a major problem of generating power from renewable options is the unreliable nature of primary RE supplies (UNCTAD 2019). Appropriate harvest of the conventional sources of RE, including solar, wind, tidal, and geothermal, in particular, is only possible during a peak period which compromises the reliability of their supplies to a large extent (McBain 2016, December 1). In this regard, Mathiesen et al. (2015) proposed the development of ICT to strengthen the energy infrastructure for facilitating use, storage, and flexible power generation activities from the RE sources. The authors asserted that the incorporation of ICT could be a solution to the limitations attached to both production and consumption of RE by smartening the conventional electricity grids, thermal grids, and gas grids, to ensure $100 \%$ RE shares in Denmark's aggregate energy consumption figures. Similarly, Bessa et al. (2014) highlighted the function of ICT in forecasting the supplies of the RE resources which, to some extent, could be ideal in diminishing the unreliability of their supplies. The authors claimed that isolating the conventional interdependent grids into smarter independent grids could foster better penetration of RE into the national energy mix. In another relevant study on the European economies, Hammons (2008) emphasized on the use of ICT to predict the wind power supply for producing wind power in Greece and The Netherlands. Moreover, Hammons (2008) also highlighted how smart gridding strategies to facilitate the integration of several RE resources into the energymixes of France, Denmark, and Italy can elevate their respective RE consumption figures.

Although ICT is expected to directly uplift the volumes of RE consumption across the globe by integrating the RE resources within the ICT commodities, it can also be an indirect medium for facilitating RE energy-use. For instance, Arnone et al. (2013, May) talked about the use of an ICT-based energy 
management system that is capable of dispatching renewable electricity, sourced from solar and wind, into smart grids and is also efficient in facilitating storage of the renewable electric power. On the other hand, the adoption of RE technologies within the developing economies, in particular, is often held back due to the lack of appropriate knowledge regarding the advantages of RE use. Hence, Fung, Tang, and Wong (2010, July) proposed a mechanism through which ICT can influence the consumer behavior of end-users of electricity in Western Australia and induce them in adopting RE technologies to meet their electricity demands. This is another such example of how ICT, apart from directly elevating the volumes of RE consumption, can also stimulate greater use of RE resources indirectly. Similarly, Ajayi and Ohijeagbon (2017) asserted that ICT can be tapped for awareness building for undergoing RET, keeping the negative environmental impacts of fossil fuel consumption into consideration, among the people living in the Southeastern regions of Nigeria.

Despite all the aforementioned studies advocating in favor of ICT attributing to the overall RET phenomenon, several studies have also shed light on ICT enhancing the overall demand for energy which is often met by power generated from the traditional NRE resources. For instance, Khayyat et al. (2016) showed that the use application of ICT in the industrial sectors of Japan and South Korea tends to replace labor with energy inputs, hence, driving up the industrial demand for energy produced from the conventional NRE resources. Similarly, Røpke and Christensen (2012) claimed that the use of ICT equipment elevates the daily energy consumption demands to a large extent. Therefore, it is ideal to invest in ICT commodities that have the provision for the employment of RE resources.

\section{The literature on ICT and energy efficiency}

ICT development is often envisioned to ensure efficient allocation of resources to which energy is no exception. Therefore, several studies, apart from probing into the ICTRE consumption nexus, have also linked ICT to the overall efficiency of energy use (Panajotovic et al. 2011). Laitner (2015) claimed that ICT is capable of curbing global energy wastes by escalating both economic and energy use efficiencies. In another study by Goldbach et al. (2018) referred to digital ICT-based energy services being key to reducing the intensity of energy use. Similarly, linking ICT to the digitization of energy-saving mechanisms, Murshed (2020b) proposed the integration of computer-programmed applications for conserving power inside university campuses in Bangladesh. In a recent study by Bastida et al. (2019), the authors claimed that ICT can stimulate changes in the behavior of households and enhance electricity use efficiencies by $0-5 \%$ in the context of the European Union economies. Such roles of ICT concerning improvement in energy use efficiencies were also remarked by Doukas et al. (2019) for the Gulf Cooperation Council member states. In another study on the Organization of Oil Exporting Countries (OPEC), Samargandi (2019) claimed that technology is a pre-requisite to enhancing energy efficiency levels as perceived from the negative correlation found between energy use intensity and technological innovation both in the short and the long runs.

Similarly, Schulte et al. (2016) found statistical evidence regarding ICT attributing to a higher incidence of energy efficiency by reducing the electricity demanded by 27 industries across 13 Organization for Economic Cooperation and Development (OECD) economies. Hence, the authors referred to ICT assisting in demand-side management of energy consumption across the concerned economies. Likewise, Voigt et al. (2014) opined that the advancement of information technology is a pre-requisite to attaining energy efficiency gains within industries across 40 major global economies. In contrast, Cho et al. (2007) found evidence in favor of the heterogeneous impacts of ICT on sectoral energy consumption figures in South Korea. The authors highlighted that investment in ICT curbed electricity demanded by the primary metalproducing industry while it elevated the volumes of electricity consumption within other industries belonging to the manufacturing and services sectors in South Korea. Besides, the roles of ICT in catalyzing energy productivity improvement in 50 developed and underdeveloped economies were described by Yan et al. 2018

Although the majority of the contemporary studies have emphasized on ICT-reducing energy consumption levels, thus implying energy efficiency gains, numerous studies have also documented evidence regarding the rebound effects associated with ICT development (Walzberg et al. 2020). Sadorsky (2012) showed that ICT attributed to higher energy electricity employment in emerging economies. In the same vein, Collard et al. (2005) said that consumption of ICT commodities elevated the intensity of electricity consumed, thus, indicating loss of energy use efficiency in six French service industries. Similar findings were reported by Bernstein and Madlener (2010) in the context of specific industries across eight European economies. Similarly, Zhou et al. (2018) stated that ICT accounted for $4.5 \%$ higher intensity of energy used by Chinese industries. Wang and Han (2016) also opined in favor of ICT elevating the energy consumption intensities across western and central regions in China.

\section{The literature on ICT and cleaner cooking fuels}

It is believed that ICT can be tapped to enhance access and employment of relatively cleaner cooking fuels. Technological constraints are said to bottleneck the prospects of transition from the use of biomass and other unhealthy cooking fuels to the modern environment and health-friendly alternative fuels for cooking purposes (Schunder and Bagchi- 
Sen 2019). In a study on the household cooking fuel consumption in Nepal, Acharya and Marhold (2019) claimed that the use of ICT applications ensured the transition from the use of the conventional firewood and kerosene fuels for cooking purposes to greater use of the comparatively cleaner alternatives like liquefied petroleum gas (LPG) and electricity. Similarly, Evans et al. (2017) stated that ICT can be a medium for awareness building, regarding the benefits of using cleaner cookstove options, amidst households in Kenya, Bangladesh, and Nigeria. Moreover, linking ICT to mass media communication, Yasmin and Grundmann (2019) showed that the mass media played a key role in facilitating the adoption of biogas for cooking in the state of Punjab in Pakistan. Kumar and Igdalsky (2019) concluded that women in Honduras and India use ICT equipment to source information concerning the advantages of using modern clean cooking fuels, thus, attributing to the gradual decline in the use of the traditionally used unclean cooking fuels. Likewise, Acharya et al. (2017) also demonstrated how ICT-enabled wireless technology, utilizing the internet of things, can enhance the efficiency levels of bio-gas generation plants.

\section{The literature on ICT and $\mathrm{CO}_{2}$ emissions}

In the contemporary era, ICT development is hypothesized to contribute to the betterment of environmental quality by curbing global emission of greenhouse gases (GHG). In a report by Malmodin and Bergmark (2015), the authors claimed that integration of ICT into the key macroeconomic sectors, including energy, can be anticipated to downsize the emission of GHG by $15 \%$ by 2030 . According to the International Energy Agency (IEA 2017a, 2017b, November), ICT has the potential to track air pollution and facilitate the capture and storage of carbons emitted into the atmosphere. Besides, the use of ICT is also expected to accelerate the process of transition from NRE to RE consumption which, in turn, would mitigate the global $\mathrm{CO}_{2}$ emission figures (IEA 2017a, 2017b). The International Renewable Energy Agency predicted that use of ICT applications within the transport sector is key to replacing the traditional fossil fuel-fired automobile engines by the modern hybrid engines that are powered by relatively cleaner fuels, thus, reducing the $\mathrm{CO}_{2}$ emissions stemming from the transportation sector in particular (IRENA 2018). Hence, it can be said that the impacts of ICT on the environment primarily depend on the capacity of the ICT to facilitate the RET phenomenon globally.

Much like the case with the RE consumption responses to ICT-trade, the nexus between ICT-trade openness and $\mathrm{CO}_{2}$ emissions is yet to be documented in the literature. However, several studies have highlighted the roles ICT development can portray concerning the betterment of the environment, particularly by curbing the $\mathrm{CO}_{2}$ emissions. Ozcan and Apergis 2018stated that Internet use accounted for lower $\mathrm{CO}_{2}$ emissions in the context of 20 emerging economies. The authors recommended the government to promote the use of the Internet as a means of reducing air pollution. Similarly, Asongu (2018) asserted that ICT, in terms of mobile and Internet uses, can be effective in reducing the environmental impacts of trade and financial liberalization concerning a panel of 44 Sub-Saharan African nations. The authors found statistical validity in the context of ICT penetration, jointly with higher trade and financial openness, reducing $\mathrm{CO}_{2}$ emissions within these economies. Godil et al. (2020) also referred to ICT being a solution to the aggravating $\mathrm{CO}_{2}$ emissions in Pakistan. The negative correlation between ICT and $\mathrm{CO}_{2}$ emissions was also highlighted in the studies by Haseeb et al. (2019) for the BRICS countries. Besides, taking the regional disparities in terms of access to ICT use across China into cognizance, Zhang and Liu (2015) concluded that ICT was responsible for lowering $\mathrm{CO}_{2}$ in China; however, these impacts were greater in the central region than in the eastern region while being insignificant for the western regions of China.

On the other hand, many existing studies have also expressed their apprehensions engulfing the detrimental impacts of ICT on the environment. In a relevant study on 23 European economies, Park et al. (2018) found statistical evidence in the context of consumption of ICT products, in terms of Internet use, to be responsible for higher $\mathrm{CO}_{2}$ emissions. However, the country-specific analysis in this regard revealed ambiguous impacts of ICT on $\mathrm{CO}_{2}$ emissions. Recently, Raheem et al. (2020) opined that ICT development attributed to environmental degradation by boosting $\mathrm{CO}_{2}$ emissions in the G7 countries. However, when interacted with financial development, a joint favorable impact on the environment was also established. In contrast, Amri et al. (2019) could not establish any statistically significant impact of ICT on $\mathrm{CO}_{2}$ emissions, neither in the short-run nor the long-run. Also, Khan et al. (2018) remarked that ICT development exerted detrimental environmental impacts on environmental quality within the Next Eleven countries. The authors claimed that greater use of the Internet was one of the main contributors to the rising $\mathrm{CO}_{2}$ emissions trends.

The non-linear impacts of ICT on $\mathrm{CO}_{2}$ emissions were examined by Faisal et al. (2020). The authors found that ICT penetration, in terms of a higher number of Internet users in Brazil, India, China, and South Africa, initially triggered $\mathrm{CO}_{2}$ emission but the relationship is reversed as the number of Internet users exceeds a threshold level. Similar results were reported by Shahnazi and Shabani (2019) in the context of Iran. Similar findings in the context of 116 developing and 26 developed nations were recognized by Higón et al. (2017). In another study in the context of Sub-Saharan Africa, Asongu et al. (2018) found an inverted-U-shaped relationship between ICT and per capita $\mathrm{CO}_{2}$ emissions while a U-shaped nexus between ICT and percentage share of $\mathrm{CO}_{2}$ emissions from liquid fuel consumption in the total $\mathrm{CO}_{2}$ emission figures. 
On the other hand, Barıș-Tüzemen et al. (2020) established an $\mathrm{N}$-shaped non-linear association between ICT, quantified in terms of the use of fixed-line phones, mobile and Internet, and $\mathrm{CO}_{2}$ emissions in Turkey. The results implied that ICT initially reduced $\mathrm{CO}_{2}$ emissions first, then increased and then reduced again.

Hence, it is obvious from the literature reviewed in this paper that greater openness to ICT trade, under appropriate liberalization frameworks, has immense potentials for fostering RE consumption, enhancing energy efficiency levels, elevating the access to cleaner cooking fuels, and improving environmental quality by reducing $\mathrm{CO}_{2}$ emissions. Figure 6 in the appendix summarizes the favorable effects of ICT trade in this regard. However, the major takeaway from this section is that there is a gap in the literature which has largely ignored the impacts of trade of ICT commodities on the prospects of RET and environmental sustainability. This paper specifically bridges this gap in the context of the South Asian economies.

\section{Model specification and data}

This paper modifies the linear econometric models used by Murhsed (Murshed 2020a to evaluate the impacts of ICTtrade openness on the prospects of undergoing RET, improving energy use efficiencies, enhancing access to clean cooking fuels, and lowering down $\mathrm{CO}_{2}$ emissions in South Asia. The model used in the study by Murshed (2020a) considered the overall trade openness index as the principal regressor of interest. However, since this paper aims to specifically address the impacts of cross-border flows of ICT commodities, the ICT-trade openness index is used instead. The corresponding regression models used in this paper can be specified as follows:

$$
\begin{aligned}
\operatorname{lnREC}_{\mathrm{it}}= & \partial_{0}+\partial_{1} \operatorname{lnIOPEN}_{\mathrm{it}}+\partial_{2} \operatorname{lnIOPEN}^{2}{ }_{\mathrm{it}}+\partial_{\mathrm{jt}} X_{j, \mathrm{it}} \\
& +\varepsilon_{\mathrm{it}} \\
\operatorname{lnRES}_{\mathrm{it}}= & \delta_{0}+\delta_{1} \operatorname{lnIOPEN}_{\mathrm{it}}+\delta_{2} \operatorname{lnIOPEN}_{\mathrm{it}}^{2}+\delta_{\mathrm{jt}} X_{j, \mathrm{it}} \\
& +\varepsilon_{\mathrm{it}} \\
\operatorname{lnEI}_{\mathrm{it}}=\theta_{0} & +\theta_{1} \operatorname{lnIOPEN}_{\mathrm{it}}+\theta_{2} \operatorname{lnIOPEN}^{2}{ }_{\mathrm{it}}+\theta_{\mathrm{jt}} \mathrm{X}_{j, \mathrm{it}} \\
+ & \varepsilon_{\mathrm{it}} \\
\operatorname{lnACFT}_{\mathrm{it}}= & \alpha_{0}+\alpha_{1} \operatorname{lnIOPEN}_{\mathrm{it}}+\alpha_{2} \operatorname{lnIOPEN}^{2}{ }_{\mathrm{it}} \\
& +\alpha_{\mathrm{kt}} Y_{k, \mathrm{it}}+\varepsilon_{\mathrm{it}}
\end{aligned}
$$

where the subscripts $i, t$, and $\varepsilon$ refer to the individual crosssectional units (countries), time periods (years), and the error terms, respectively. $\partial, \delta, \theta$, and $\alpha$ are the intercepts and the elasticity parameters to be estimated. The dependent variables used in models 1 and 2 are used as indicators of RET within the selected South Asian economies. REC refers to RE consumption in terms of terajoules while RES stands for the percentage share of RE consumption in total energy consumption levels. Model 3 scrutinizes the conditional impacts of ICT trade on energy efficiency levels. EI abbreviates for the intensity of energy-use which is expressed as the volume of energy used to produce one unit of GDP. This particular variable captures the efficiency of energy employment whereby lower values of EI refers to higher efficiencies of energy use and vice-versa. Model 4 estimates the conditional impacts of ICT trade on access to cleaner cooking fuel options. ACFT is the short form for access to clean fuels and technologies for cooking purposes which is given by the percentage of the population having access to the relatively cleaner cooking fuel options. The principal regressor of interest IOPEN abbreviates for the ICT-trade openness index which is measured in terms of the sum of real values of ICT imports and exports as a percentage of the real GDP of the respective economies. A higher value of this index can be interpreted as higher degrees of ICT traded by the selected South Asian economies and vice-versa. Moreover, to account for the possible nonlinearity of the nexus between ICT-trade openness and the aforementioned response variables, the squared term of the ICT-trade openness index $\left(\mathrm{IOPEN}^{2}\right)$ is included in the empirical models. The inclusion of the squared term is grounded on the assumption that ICT penetration, through cross-border flows of ICT commodities, may not be effective in influencing the dependent variables from the onset. However, beyond a certain level of ICT-trade, positive influences of ICT use in this regard could be expected.

In models 1,2 , and $3, X$ is set of $j(j=1,2, \ldots, 7)$ key macroeconomic control variables that are believed to influence REC, RES, and EI which includes per capita $\mathrm{CO}_{2}$ emissions measured in metric tons, world real crude oil prices (OIL) in 2016 US dollars per barrel, net inflows of foreign direct investments (FDI) in constant 2010 US dollars, net official development assistance (NODA) received in terms of 2010 constant US dollars, international remittance inflows (REMIT) in 2010 constant US dollars, Gross National Product (GNI) per capita (GNIPC) measured in terms of 2010 constant US dollars, and consumer price index (CPI) to proxy for the domestic inflationary rates. On the other hand, in model $4, Y$ is a vector of $k(k=1,2, \ldots, 5)$ control variables that are expected to affect ACFT which includes per capita $\mathrm{CO}_{2}$, world crude oil prices, inflationary rates, life expectancy at birth (LIFE), and secondary school enrolment rates (SSE). ${ }^{7}$ Following Murshed and Tanha (2020), the squared terms of real crude oil prices $\left(\mathrm{OIL}^{2}\right)$ are included into the models to account for the oil-import dependency among the South Asian economies which could initially hamper the substitution of oil

\footnotetext{
${ }^{7}$ For justification regarding the inclusion of the life expectancy at birth and secondary school enrolment rates variables into model 4, see Murshed (2018).
} 
consumption via the $\mathrm{RE}$ alternatives following a rise in crude oil prices in the international markets. Murshed and Tanha (2020), in line with their empirical findings, recommended South Asian economies including Bangladesh, India, Pakistan, and Sri Lanka to lessen their reliance on oil imports in order to undergo RET. On the other hand, a squared term of the GNI per capita variable $\left(\mathrm{GNIPC}^{2}\right)$ is included in each of the regression models for evaluating the possible non-linear growth impacts on REC, RES, EI, and ACFT. The fundamental reason behind its inclusion into the models could be explained by the fact that all selected South Asian nations are developing economies with low levels of technological innovation in the majority of the cases. Thus, the initial impacts of economic growth could either be negligible or unfavorable which can be anticipated to be reversed at higher growth levels (Murshed 2020a).

Besides, in order to estimate the effects of ICT-trade on environment well-being, the per capita $\mathrm{CO}_{2}$ emissions are used as response variables to proxy for the quality of environment across South Asia. The econometric models in this regard are given by the following equations:

$$
\begin{aligned}
\operatorname{lnCO}_{i \mathrm{it}}= & \mu_{0}+\mu_{1} \operatorname{lnIOPEN}_{\mathrm{it}}+\mu_{2} \operatorname{lnIOPEN}^{2}{ }_{\mathrm{it}} \\
& +\mu_{3} \operatorname{lnREC}_{\mathrm{it}} \\
& +\mu_{4}\left(\operatorname{lnIOPEN} \times \operatorname{lnREC} \mathrm{lit}_{\mathrm{it}}\right)+\mu_{5} \operatorname{lnEI}_{\mathrm{it}} \\
& +\mu_{6}(\operatorname{lnIOPEN} \times \operatorname{lnEI} \mathrm{it})+\mu_{7} \ln _{\mathrm{ACFT}}{ }_{\mathrm{it}} \\
& +\mu_{8}\left(\operatorname{lnIOPEN} \times \ln \mathrm{lCFT}_{\mathrm{it}}\right)+\mu_{9} \operatorname{lnOIL}_{\mathrm{it}} \\
& +\mu_{10} \operatorname{lnGNIPC}_{\mathrm{it}}+\mu_{11} \operatorname{lnGNIPC}_{\mathrm{it}}^{2}+\varepsilon_{\mathrm{it}}
\end{aligned}
$$

$$
\begin{aligned}
\operatorname{lnCO}_{2 \mathrm{it}}= & \pi_{0}+\pi_{1} \operatorname{lnIOPEN}_{\mathrm{it}}+\pi_{2} \operatorname{lnIOPEN}^{2}{ }_{\mathrm{it}} \\
& +\pi_{3} \operatorname{lnNREC}_{\mathrm{it}} \\
& +\pi_{4}(\operatorname{lnIOPEN} \times \operatorname{lnNREC} i \mathrm{it})+\pi_{5} \operatorname{lnEI}_{\mathrm{it}} \\
& +\pi_{6}\left(\operatorname{lnIOPEN} \times \operatorname{lnEI} \mathrm{it}_{\mathrm{it}}\right)+\pi_{7} \ln _{\mathrm{ACFT}} \mathrm{it} \\
& +\pi_{8}\left(\operatorname{lnIOPEN} \times \ln \mathrm{nCFT}_{\mathrm{it}}\right)+\pi_{9} \operatorname{lnOIL}_{\mathrm{it}} \\
& +\pi_{10} \operatorname{lnGNIPC}_{\mathrm{it}}+\pi_{11} \operatorname{lnGNIPC}^{2}{ }_{\mathrm{it}}+\varepsilon_{\mathrm{it}}
\end{aligned}
$$

where $\mu$ and $\pi$ are the elasticity parameters to be estimated. NREC refers to NRE consumption measured in terms of terajoules. In order to assess the heterogeneous impacts of different energy types on $\mathrm{CO} 2$ emissions, REC and NREC are included in separate models. ${ }^{8}$ Once again, the squared term of the ICT trade openness index is expected to capture

\footnotetext{
$\overline{8}$ The decision to include REC and NREC in separate models was made to avoid the potential multicollinearity and endogeneity issues.
}

the possible non-linearity between ICT trade and $\mathrm{CO}_{2}$ emissions. It is pertinent to evaluate the non-linear association in this regard since many studies have referred to ICT penetration, in terms of higher uses of mobile phones and Internet services, exhibiting non-linear relationships with $\mathrm{CO}_{2}$ emissions (Asongu et al. 2018). Both the models are also controlled for the level of energy use intensities since lower intensity levels can be linked to lower energy consumption and therefore lower $\mathrm{CO}_{2}$ emissions as well. Similarly, access to cleaner fuels and technology is included in the models from the understanding that enhancing access to these cleaner fuels could replace the traditional environmentally unfriendly cooking fuels and mitigate the $\mathrm{CO}_{2}$ emissions. More importantly, in order to account for the possible indirect impacts of ICT trade on $\mathrm{CO}_{2}$ emissions, the ICT-trade openness variable is interacted with REC, NREC, EI, and ACFT to evaluate their joint impacts on $\mathrm{CO}_{2}$ emissions. Statistical significance of the elasticity parameters attached to the interaction terms would provide statistical support in favor of ICT trade influencing the $\mathrm{CO}_{2}$ emissions indirectly.

Besides, the squared term of the per capita GNI figures is used to account for the possible non-linear relationship between economic growth and carbon emissions. The signs of the elasticity parameters attached to GNIPC and its squared terms would provide statistical support to validate/invalidate the existence of the Environmental Kuznets Curve (EKC) hypothesis. ${ }^{9}$ Unlike the cases in the context of models 1, 2, 3, and 4 , the squared terms of real crude oil prices were dropped from models 5 and 6 due to the statistical insignificance of estimates of the corresponding elasticity parameters upon their inclusion into the models.

All the variables have been transformed into their natural logarithms (prefixed by $l n$ ) for the ease of estimating the conditional bivariate elasticity. Annual time-series data from 2000 to 2016 is compiled in the context of all the six selected South Asian economies. The crude oil price data has been sourced from the British Petroleum Statistical Review of World Energy (BP 2019) database while data for the rest of the variables are generated from the World Development Indicators database of the World Bank (2020).

\section{Methodology}

This paper employs panel data estimation techniques that are robust to handling cross-sectionally dependent panel series. In comparison to the country-specific time-series econometric methods, the panel data provides methodology which generates better estimates of the dynamic changes of variables over time, and the associated estimation techniques involve a group of countries with inter cross-sectional (or different) and/or

\footnotetext{
${ }^{9}$ For more information on the EKC hypothesis see Pata (2018).
} 
intra cross-sectional (or common) characteristics (Baltagi 2008). In addition, the panel data analysis allows for less collinearity among the variables (Gujarati 2005) and higher degrees of freedom (Hsiao 2005) and produces relatively more efficient estimates (Baltagi 2013). Moreover, panel data is better suited to accommodating the possible omitted variable biases in the dataset (Hsiao 2007). The econometric analysis conducted in this paper commences by checking for crosssectional dependence among the panel series.

\section{Cross-sectional dependency analysis}

The problem of cross-sectional dependence leads to biased and inconsistent outcomes. Hence, before investigating the stationarity and the cointegrating properties, it is pertinent to investigate whether the cross-sections are independent or not. Crosssectional dependence usually arises when one economic data of a particular country is influenced via the same economic data in another country whereby the countries within the panel dataset are referred to be either globally or regionally associated. This paper taps the Pesaran Cross-sectional Dependency (CD) and the Breusch-Pagan Lagrange Multiplier (LM) tests, respectively, introduced by Pesaran (2004) and Breusch and Pagan (1980), for this purpose. Both the tests spit out a test statistic that is tested under the null hypothesis of cross-sectional independence against the alternative hypothesis of otherwise. For a model comprising of $N$ number of cross-sections for the time period $T$, the test statistics of the CD and LM tests can be given by the following equations:

$\mathrm{CD}=\sqrt{\frac{2}{N(N-1)}} \sum_{i=1}^{N-1} \sum_{j=i+1}^{N} T_{\mathrm{ij}} \widehat{\rho}_{\mathrm{ij}}^{2} \rightarrow N(0,1)$

$\mathrm{LM}=\sum_{i=1}^{N-1} \sum_{j=i+1}^{N} T_{\mathrm{ij}} \hat{\rho}_{\mathrm{ij}}^{2} \rightarrow \chi^{2} \frac{N(N-1)}{2}$

The panel unit root analysis follows the cross-sectional dependency investigations.

\section{Panel unit root analysis}

In the context of the panels being interlinked, the application of the first generation panel data unit root estimation techniques is no longer appropriate due to these tests not being able to account for cross-sectional dependency. Thus, the second generation panel unit root tests that are robust to handling cross-sectional dependency in the data are used. This paper uses the Cross-sectionally Augmented Dickey-Fuller (CADF) and the cross-sectionally augmented Im, Pesaran, and Shin (CIPS) unit root estimation techniques proposed by Pesaran
(2007). The CADF statistic can be obtained from the regression given below:

$$
\begin{aligned}
\Delta y_{\mathrm{it}}= & a_{i}+b_{i} y_{\mathrm{i}, t-1}+c_{i} \bar{y}_{t-1}+\sum_{j=0}^{s} d_{\mathrm{ij}} \Delta \bar{y}_{t-j} \\
& +\sum_{j=1}^{s} \delta_{i j} \Delta \bar{y}_{i, t-j}+e_{\mathrm{it}}
\end{aligned}
$$

where $\bar{y}$ and $\Delta \bar{y}$ are the cross-sectional averages of lagged levels and first differences, respectively, at time $T$ for all countries. The estimated $t$-statistic from equation (9) is then used to compute the CIPS statistic which can be shown as:

$\mathrm{CIPS}=N^{-1} \sum_{i=1}^{N} \mathrm{CADF}_{i}$

where $\mathrm{CADF}_{i}$ is the $t$ statistic estimated from CADF regression model shown in equation (9). Both the CADF and CIPS tests are performed under the null hypothesis of nonstationarity of the variables against the alternative hypothesis of otherwise. The panel cointegration analysis follows the unit root tests.

\section{Panel cointegration analysis}

Likewise, the first generation panel unit root tests, the conventional panel cointegration estimator such as the Pedroni (1999) residual-based cointegration technique does not take the cross-sectional dependency within the panels into account. Thus, the Westerlund (2007) panel cointegration analysis, which is robust to handling cross-sectionally dependent panel dataset, is employed to investigate the long-run associations between the variables. Cross-sectional dependency is accounted for via estimation of the probability values of the test statistics via bootstrapping methods. A total of two groupmean tests and two panel tests are performed under the null hypothesis of no cointegration against the alternative hypothesis of cointegration among at least one cross-sectional unit or cointegration among the whole panel, respectively. The Westerlund (2007) tests are structured in the context of an error-correction model which can be expressed as:

$$
\begin{aligned}
\Delta y_{\mathrm{it}}= & \delta_{i}^{\prime} d_{t}+\alpha_{\mathrm{i}}\left(\mathrm{y}_{\mathrm{i}, \mathrm{t}-1}-\beta_{i}^{\prime} x_{i, t-1}\right)+\sum_{j=1}^{p_{i}} \alpha_{\mathrm{ij}} \Delta y_{i, t-j} \\
& +\sum_{-q_{i}}^{p_{i}} \gamma_{\mathrm{ij}} \Delta x_{i, t-j}+e_{\mathrm{it}}
\end{aligned}
$$

where $d_{t}$ stands for the deterministic components and $p_{i}$ and $q_{i}$ are the lag lengths and lead orders which vary across individual cross-sections. The two group-mean test statistics $G_{t}$ and $G_{a}$ and the two panel test statistics $P_{t}$ and $P_{a}$ within the Westerlund (2007) cointegration analysis can be shown as follows: 


$$
\begin{aligned}
G_{t} & =\frac{1}{\mathrm{~N}} \sum_{i=1}^{N} \frac{\widehat{\alpha}_{i}}{\operatorname{SE}\left(\widehat{\alpha}_{i}\right)} \\
G_{a} & =\frac{1}{N} \sum_{i=1}^{N} \frac{T \widehat{\alpha}_{i}}{\widehat{\alpha}_{i}(1)} \\
P_{t} & =\frac{\widehat{\alpha}_{i}}{\operatorname{SE}\left(\widehat{\alpha}_{i}\right)} \\
P_{a} & =T \widehat{\alpha}
\end{aligned}
$$

\section{Panel regression analysis}

This paper employs the continuously updated fully modified (CUP-FM) and the continuously updated bias corrected (CUP-BC) panel cointegrating regression estimators, proposed by Bai et al. (2009) to estimate the long-run elasticities of the energy and environmental sustainability indicators with respect to ICT-trade openness in the presence of key macroeconomic control variables. Both these techniques are said to generate robust results in the presence of endogeneity and cross-sectional dependency issues with the dataset and can also accommodate mixed order of integration among the variables in the respective models. The regression function of a CUPFM and CUP-BC model can be shown as follows:

$$
\left(\widehat{\beta}_{\mathrm{CUP}}, \widehat{F}_{\mathrm{CUP}}\right)=\operatorname{argmin} \frac{1}{n T^{2}} \sum_{i=1}^{n}\left(y_{i}-x_{i} \beta\right)^{\prime} M_{F}\left(y_{i}-x_{i} \beta\right)
$$

where $M_{F}=I_{T}-T^{-2} \mathrm{FF}$, and $I_{T}$ and $F$ are the identity of matrix dimension $T$, and the error term assumes a latent common factor. In the context of the continuously biased estimators being consistent, asymptotic bias may arise from the endogeneity and the cross-sectional dependency problems. Although both the CUP-FM and the CUP-BC corrects for this asymptotic bias, the difference between these two estimators is that the CUP-FM estimator corrects for the bias correction only in the final stage of the iteration while the CUP-BC corrects it at each stage of the iteration. For robustness checks, this study taps the feasible generalized least squares (FGLS) estimator as well.

\section{Heterogeneous panel causality analysis}

The newly developed Dumitrescu-Hurlin panel causality estimation technique by Dumitrescu and Hurlin (2012) is applied to investigate the causal dynamics between openness to ICT-trade and the energy and environment indicators considered in this paper. The conventional Granger (1969) causality test inappropriate assumes homogeneity across the cross-sections whereby the test statistic is estimated using the null hypothesis that Granger causality does not exist between a pair of stationary variables belonging to all the cross-sections against the homogenous alternative hypothesis of Granger causality existing between these variables in all the cross-sections. Thus, this method does not take the heterogeneity across the cross-sections into consideration which results in biased causality estimates. In contrast, the DumitrescuHurlin causality technique allows for heterogeneity across the cross-sections to estimate the $Z$-bar statistic using the null hypothesis that there does not exist a Granger causality between a pair of stationary variables in all the crosssections, referred to as the homogenous non-causality (HNC) null hypothesis, against the non-homogenous alternative hypothesis of Granger causality existing between these variables in at least one of the cross-sections. The mean statistic used to test the HNC null hypothesis can be given as follows:

$W_{N, T}^{\mathrm{HNC}}=\frac{1}{N} \sum_{i=1}^{N} W_{i, T}$

where $W_{N, T}^{\mathrm{HNC}}$ is the mean value of the individual Wald statistic $W_{i, t}$. According to Dumitrescu and Hurlin (2012), under the assumption that the individual residuals are independently distributed across all the cross-sections and their covariances are equal to zero, the mean statistic sequentially converges to the equation below when $T$ and $N$ tend to approach infinity:

$Z_{N, T}^{\mathrm{HNC}}=\sqrt{\frac{N}{2 K}}\left(W_{N, T}^{\mathrm{HNC}}-K\right)_{T, N \rightarrow \infty}^{\vec{d}} N(0,1)$

where $Z_{N, T}^{\mathrm{HNC}}$ is the $Z$-statistic, $N$ is the number of crosssections and $K$ is the optimal lag length. According to Dumitrescu and Hurlin (2012), if $T$ tends to infinity, the individual Wald statistics are independently identically distributed with the mean individual Wald statistic being equal to $K$ and its variance being equal to $2 \mathrm{~K}$. A standardized Z-statistic $\left(\bar{Z}_{N, T}^{\mathrm{HNC}}\right)$ is then approximately calculated for the mean Wald statistic of the HNC null hypothesis which can be shown as follows:

$\bar{Z}_{N, T}^{\mathrm{HNC}}=\frac{\sqrt{N}}{\sqrt{\operatorname{Var}\left(\widetilde{W}_{i, T}\right)}}\left[W_{N, T}^{\mathrm{HNC}}-\mathrm{E} \widetilde{\mathrm{W}}_{i, T}\right]$

The statistical significance of the standardized $Z$-statistic determines the causality between a pair of stationary variables in at least one of the cross-sections. For robustness check, the 
Granger (1969) causality and the Geweke's (1982) measure of instantaneous feedback techniques are also tapped to deduce the causal associations.

\section{Results and discussion}

Table 2 reports the results from the $\mathrm{CD}$ analyses for all the respective models. The statistical significance of the predicated test statistics from both the Pesaran (2004) and BreuschPagan (Breusch and Pagan 1980) LM tests affirm the presence of $\mathrm{CD}$ among the panel series. These results implicate that a change in a particular explanatory variable in one of the six South Asian nations influences the corresponding variable in at least one of the other five nations as well. As a result, ignoring the $\mathrm{CD}$ issues in the data is likely to generate biased estimates of the stationarity and cointegrating properties. This justifies the decision to employ the second-generation panel unit root and cointegration methods, in this paper, that are robust to handling cross-sectionally dependent panels.

The results from the second generation panel unit root tests are presented in Table 3. The estimated test statistics from both the CIPS and CADF tests confirm a common order of integration among the variables considered in the empirical analyses. The results show that all the variables are non-stationary at their respective level forms but they do become stationary at their first difference, thus, indicating that the variables are commonly integrated at I(1). These imply that all the variables are mean-reverting at their first differences whereby the possibility of performing spurious regression analyses using these data is nullified.

Upon confirmation of the stationarity properties, the secondgeneration panel cointegration analysis is performed. The corresponding cointegration results from the Westerlund (2007) test, as reported in Table 4, suggest cointegrating relationships between the variables in all the regression models. The statistical significance of the predicted test statistics, at $1 \%$ and $5 \%$ levels, affirms this claim. Therefore, it can be asserted that there are long-run associations between ICT-trade openness, consumption of RE energy, the share of RE in total final energy consumption figures, energy use intensity, access to cleaner cooking fuels, and $\mathrm{CO}_{2}$ emissions. The confirmation of the cointegrating associations meets the pre-requisite to estimating the long-run elasticities using the appropriate panel regression estimators.

The results from the panel data regression analyses in the context of models (1), (2), and (3) are reported in Table 5. For robustness check of the elasticity estimates, different panel data regression techniques, robust to handling $\mathrm{CD}$ issues, are tapped. The identical signs and the statistical significance of the elasticity estimates confirm the robustness of the findings across the different panel regression approaches used in this paper.

In the context of model (1), the long-run elasticity estimates suggest that higher openness to ICT trade monotonically increases the levels of RE within the selected South Asian economies. The positive signs of the statistically significant elasticity parameters, at $1 \%$ and $5 \%$ levels, attached to ICTtrade openness index and its squared term affirm this claim. A $1 \%$ rise in the ICT trade openness index initially accounts for a rise in the RE consumption levels by $0.40-0.52 \%$, on average, ceteris paribus; while the positive impacts are intensified further at higher levels of ICT-trade openness indices as well. Therefore, in line with these empirical findings, liberalization of the barriers to ICT-trade could be considered as a solution to the low RE consumption figures in most of the South Asian economies of concern. Moreover, it is likely that facilitating the cross-border flows of the ICT goods across South Asia would eventually bridge the technological backwardness within these most of these nations that had traditionally hampered the prospects of switching from consumption of NRE to RE resources. Consequently, it is ideal for the government to consider restructuring the tariff policies concerning ICT imports in particular which, in turn, can be anticipated to induce technological spillovers through the development of the ICT sectors of the respective South Asian economies. These results partially echo with the findings reported by Murshed (2018) in which the author claimed trade liberalization to stimulate RE consumption in Bangladesh, India, Pakistan, Sri Lanka, and Nepal. The positive correlation between ICT-trade openness and RE consumption also implies that the use of the imported ICT commodities is capable of influencing RE adoption behavior, both directly and indirectly, among the population of the respective South Asian economies. Hence, the findings, in this regard, can also be related to the conclusions put forward by Fung, Tang, and Wong (2010, July) and Ajayi and Ohijeagbon (2017) for Western Australia and Nigeria, respectively. Furthermore, the positive ICT-trade openness-RE consumption nexus also highlights the significance of promoting trade of ICT with respect to mitigating energy crises and enhancing grid reliability in South Asia whereby the use of ICT, by facilitating RE consumption within these economies, is likely to make sure that the RE resources complement the NRE resources in meeting the overall energy demand in South Asia.

Among the other key determinant of RE consumption across South Asia, the elasticity estimates in the context of model (1) reveal that rising levels of $\mathrm{CO}_{2}$ emissions stimulate greater consumption of RE resources. The positive signs of the statistically significant elasticity parameters attached to $\mathrm{CO}_{2}$ suggest that $\mathrm{RE}$ consumption in this region is driven by the climate change apprehensions stemming from the rise in the volumes of $\mathrm{CO}_{2}$ emissions in South Asia. The corresponding elasticity estimates show a $1 \%$ rise in per capita $\mathrm{CO}_{2}$ emissions enhances the $\mathrm{RE}$ consumption levels, on average, by $0.08-0.13 \%$ ceteris paribus. The positive $\mathrm{RE}$ consumption- $\mathrm{CO}_{2}$ emissions nexus was also found in the studies by Apergis and Apergis (2017).

Besides, positive shocks to the world crude oil prices, initially, are found to dampen the RE consumption levels across the South Asian economies of concern. However, at substantially higher 
Table 2 Cross-sectional dependency analysis

\begin{tabular}{|c|c|c|c|c|c|c|}
\hline Model & (1) & (2) & (3) & (4) & (5) & (6) \\
\hline Dependent variable & $\operatorname{lnREC}_{t}$ & $\operatorname{lnRES}{ }_{t}$ & $\operatorname{lnEI_{t}}$ & $\ln \mathrm{ACFT}_{t}$ & $\operatorname{lnCO} 2_{t}$ & $\operatorname{lnCO} 2_{t}$ \\
\hline CD-tests & $\begin{array}{r}-1.833^{*} \\
(0.076)\end{array}$ & $\begin{array}{r}1.901 * * \\
(0.039)\end{array}$ & $\begin{array}{r}-1.767 * \\
(0.069)\end{array}$ & $\begin{array}{r}-1.712 * * \\
(0.049)\end{array}$ & $\begin{array}{r}-1.882 * * \\
(0.026)\end{array}$ & $\begin{array}{r}4.003 * * * \\
(0.000)\end{array}$ \\
\hline LM-tests & $\begin{array}{r}74.231 * * * \\
(0.000)\end{array}$ & $\begin{array}{r}70.719 * * * \\
(0.000)\end{array}$ & $\begin{array}{r}56.298 * * * \\
(0.001)\end{array}$ & $\begin{array}{r}66.291 * * * \\
(0.001)\end{array}$ & $\begin{array}{r}89.230 * * * \\
(0.000)\end{array}$ & $\begin{array}{r}75.249 * * * \\
(0.000)\end{array}$ \\
\hline
\end{tabular}

The optimal lags are based on Schwarz Information Criterion (SIC); The probability values are reported within the parentheses. $* * * * *$, and $*$ denote statistical significance at $1 \%, 5 \%$, and $10 \%$ levels respectively crude oil prices, the relationship reverses to promote greater consumption of renewables in these economies. This non-linear oil price-RE consumption nexus is parallel to the findings by Murshed and Tanha (2020) where the authors recommended for drifting away from imported crude-oil dependency as a means to undergoing RET in four South Asian net oilimporting economies. On the other hand, the inflow of foreign direct investments and official development assistance are seen to dampen the RE consumption levels. A plausible explanation behind these findings could be that the foreign funds received by the South Asian nations are probably directed at industries that intensively use the NRE resources. The negative FDI inflowRE consumption nexus found in this paper partially validates the existence of the pollution haven hypothesis ${ }^{10}$, thus, implicating that the foreign investors often exploit the weak environmental regulations across South Asia to outsource production of dirty commodities which particularly embody the NRE energy resources. On the other hand, incoming foreign remittances are found to facilitate RE consumption to a large extent. A $1 \%$ rise in remittance inflows is seen to enhance the average RE consumption levels by $0.40-0.42 \%$, ceteris paribus. This particular finding is credible in the sense that remittances from expatriates have become a significant source of household income, especially for the remittance-receiving family members in the rural areas. Hence, the remitted funds could act as a boost to their purchasing power capacities and standard of living, thus, uplifting their financial capacities to consume the RE resources. This finding corroborates with the results presented by Khan et al. (2020) in the context of the BRICS countries.

Moreover, the non-linear economic growth impacts on the RE consumption figures are also seen from the negative and positive signs of the predicted elasticity parameters attached to GNIPC and its squared term. These imply that economic growth in the early stages does not stimulate consumption of renewables primarily due to the scale and composition effects which induce production of the national output by employing the NRE resources. However, in the latter stages of growth, the technique effect tends to dominate the scale and composition effects to induce greater consumption of RE resources. ${ }^{11}$ These results

\footnotetext{
${ }^{10}$ For more information on the pollution haven hypothesis see Cole (2004).

${ }^{11}$ For in-depth information regarding the scale, composition and technique effects associated with economic growth see Tsurumi and Managi (2010).
}

corroborate with the findings by Murshed (2020a) in the context of lower-middle-income economies. Finally, RE consumption is found to be negatively influenced by the domestic inflationary pressures which, to some extent, tend to reduce the purchasing power of the people to dampen the RE figures across South Asia.

In the context of model (2), the long-run elasticity estimates reported in Table 5 provide statistical support in favor of a non-linear U-shaped association between ICT-trade openness and RE consumption in South Asia. The negative and positive signs of the statistically significant elasticity parameters attached to OPEN and its squared term imply that liberalizing the barriers to ICT trade initially does not enhance the share of renewables in the aggregate final energy consumption figures. However, with time, higher degrees of openness to ICT trade does account for higher RE shares. These imply that the positive impacts of ICT trade on the prospects of undergoing RET are evident only at substantially high degrees of openness to ICT-trade. This calls for a persistent reduction in the associated barriers that uphold the cross-border exchange of ICT commodities across South Asia. Hence, it can be asserted that the development of the ICT sectors in South Asia, through gradual facilitation of ICT trade, is essential in overcoming the initial adverse impacts associated with the liberalization of the ICT trade barriers on the RET phenomenon. Moreover, it must be kept under consideration that the reduction in the trade barriers should be relatively higher in the context of trade of green ICT commodities which would ideally complement the policies aimed at undergoing RET to a large extent.

Apart from higher degrees of ICT-trade openness, the RE shares in aggregate final energy consumption figures are found to be positively influenced by rising volumes of $\mathrm{CO}_{2}$ emission. A $1 \%$ rise in $\mathrm{CO}_{2}$ emissions is calculated to increase RE consumption levels by $3-3.48 \%$, on average, ceteris paribus. These results, much like the corresponding elasticity estimates in the context of model (1), denote that apprehension regarding the $\mathrm{CO} 2$ emission-induced climate change adversities not only triggers greater consumption of the RE resources, but it also tends to foster the process of RET by simultaneously reducing the use of the NRE resources as well. Consequently, the overall shares of $\mathrm{RE}$ in total final energy consumption figures in South Asia and per capita $\mathrm{CO}_{2}$ emissions tend to go up in tandem. On the other hand, the long-run elasticity estimates also provide statistical 
Table 3 The panel unit root test results

\begin{tabular}{|c|c|c|c|c|}
\hline \multirow[t]{2}{*}{ Variables } & \multicolumn{2}{|l|}{ CIPS } & \multicolumn{2}{|l|}{ CADF } \\
\hline & Level, I(0) & 1st difference, I(1) & Level, I(0) & 1st difference, I(1) \\
\hline $\operatorname{lnREC}$ & -2.013 & $-5.299 * * *$ & -2.388 & $-3.798 * * *$ \\
\hline $\operatorname{lnRES}$ & -2.004 & $-4.238 * * *$ & -1.219 & $-2.389 *$ \\
\hline $\operatorname{lnEI}$ & -2.154 & $-5.149 * * *$ & -2.001 & $-3.634 * * *$ \\
\hline $\ln \mathrm{ACFT}$ & -1.854 & $-4.775 * * *$ & -2.149 & $-3.287 * * *$ \\
\hline $\operatorname{lnIOPEN//nIOPEN}{ }^{2}$ & -2.634 & $-5.152 * * *$ & -2.281 & $-3.346 * * *$ \\
\hline $\operatorname{lnCO} 2$ & -2.164 & $-4.825 * * *$ & -1.307 & $-3.302 * * *$ \\
\hline $\operatorname{lnOIL} / \operatorname{lnOIL}^{2}$ & 1.719 & $4.701 * * *$ & 1.700 & $3.107 * * *$ \\
\hline $\operatorname{lnFDI}$ & -2.618 & $-4.133 * * *$ & -2.436 & $-3.364 * * *$ \\
\hline $\operatorname{lnNODA}$ & -2.578 & $-5.658 * * *$ & -2.819 & $-3.561 * * *$ \\
\hline $\operatorname{lnREMIT}$ & -1.969 & $-3.169 * *$ & -2.512 & $-3.430 * * *$ \\
\hline $\operatorname{lnGNIPC/lnGNIPC}{ }^{2}$ & -2.298 & $-2.760^{*}$ & -1.461 & $-3.590 * * *$ \\
\hline $\operatorname{lnCPI}$ & -2.408 & $-3.928 * * *$ & -2.236 & $-3.685 * * *$ \\
\hline $\operatorname{lnSSE}$ & -1.897 & $-3.088 * *$ & -1.355 & $-3.304 * * *$ \\
\hline $\operatorname{lnLIFE}$ & 1.181 & $-4.723 * * *$ & -2.218 & $-4.067 * * *$ \\
\hline $\operatorname{lnEC}$ & -1.084 & $-4.431 * * *$ & -2.410 & $-3.640 * * *$ \\
\hline $\operatorname{lnIOPEN} * \ln R E C$ & -1.991 & $-5.247 * * *$ & -2.248 & $-3.476 * * *$ \\
\hline $\operatorname{lnIOPEN} * \ln N R E C$ & -1.688 & $-5.437 * * *$ & -2.314 & $-3.482 * * *$ \\
\hline
\end{tabular}

The estimates are calculated considering trends and the optimal lags are based on SIC; ***, **, and * denote statistical significance at $1 \%, 5 \%$, and $10 \%$ levels respectively validity for the non-linear U-shaped association between real crude oil prices and the RE shares. This implies that small hikes in the world crude oil prices are not sufficient in elevating the shares of RE use in the total final energy consumption figures. However, a substantial rise in the oil prices is found to facilitate RET in the South Asian economies by escalation their respective RE shares. The results are identical to the conclusions by Muntasir and Tanha (Murshed and Tanha 2020).

As far as financial globalization is concerned, it can be seen that income foreign direct investments deteriorate the RE shares of the South Asian economies. The marginal effect of a rise in net foreign direct inflows reduces the RE shares on average by $5.12-6.58 \%$, ceteris paribus. Once again the partial validity to the pollution haven hypothesis is affirmed by this finding which calls for channeling the foreign funds towards industries that are intensive in the use of RE resources. Likewise, inflows of official development assistance are also found to hamper the overall RET phenomenon by reducing the RE shares. A rise in the net official development assistance by $1 \%$ reduces RE shares by $8.19-9.19 \%$, on average, ceteris paribus. Therefore, it is ideal for the South Asian economies to abate the proportion of dirty aids in their respective aggregate foreign aid figures in order to undergo RET in this region. This finding eclipses the conclusions regarding the negative correlation between foreign direct investments and RE shares for developing economies by Marton and Hagert (2017). The long-run elasticity estimates also affirm that international migration is key for the South Asian economies to undergo RET which can be perceived from the positive sign of estimated elasticity parameter attached to REMIT. A rise in the foreign remittance received by $1 \%$ is associated with a rise in the RE shares by $10.47-11.53 \%$, on average, ceteris paribus. Besides, economic growth found to reduce the shares of RE. The negative signs of the statistically significant predicted elasticity parameters attached to GNIPC and its squared terms affirm this claim. However, the magnitudes of the elasticity estimate concerning the squared term of GNIPC are relatively smaller which implicate that as higher levels of national income the detrimental impacts on the RET phenomenon, to some extent, seem to diminish. These findings do not support the corresponding findings by Murshed (2020a) for low- and middle-income economies.

The long-run elasticity estimates in the context of model 3, as shown in Table 5, provide statistical support to validate the non-linear relationship between ICT-trade openness and energy use efficiencies. The corresponding elasticity estimates reveal that higher degrees of ICT-trade openness initially reduce the energy efficiency levels by increasing the intensities of energy use. However, substantial rises in the ICT-trade openness indices are likely to improve energy efficiencies in the future by dampening the intensities of energy use. Therefore, it can be asserted that ICT development, along with gradual penetration within the ICT-importing South Asian economies, is the longrun solution concerning the enhancement of energy use efficiency levels in this region. Thus, the gradual liberalization of the associated barriers to ITC trade has critically important roles to play in this regard. The initial negative impacts of ICT-trade openness on energy efficiency can be compared to the results 
Table 4 Westerlund (2007) cointegration analysis

\begin{tabular}{|c|c|c|c|c|}
\hline Model & Statistic & Value & $Z$ value & $P$ value \\
\hline \multirow[t]{4}{*}{ (1) } & $G_{t}$ & -7.724 & -6.627 & 0.000 \\
\hline & $G_{a}$ & -6.819 & 3.492 & 0.000 \\
\hline & $P_{t}$ & -4.931 & 2.168 & 0.005 \\
\hline & $P_{a}$ & -4.545 & 3.002 & 0.004 \\
\hline \multirow[t]{4}{*}{ (2) } & $G_{t}$ & -5.004 & -2.995 & 0.000 \\
\hline & $G_{a}$ & -7.159 & 3.664 & 0.000 \\
\hline & $P_{t}$ & -8.159 & -3.182 & 0.000 \\
\hline & $P_{a}$ & -7.290 & 3.563 & 0.000 \\
\hline \multirow[t]{4}{*}{ (3) } & $G_{t}$ & -2.921 & 3.098 & 0.021 \\
\hline & $G_{a}$ & -15.030 & -4.293 & 0.000 \\
\hline & $P_{t}$ & -12.722 & -2.236 & 0.000 \\
\hline & $P_{a}$ & -9.521 & -3.122 & 0.000 \\
\hline \multirow[t]{4}{*}{ (4) } & $G_{t}$ & -12.422 & 3.252 & 0.000 \\
\hline & $G_{a}$ & -12.124 & 4.223 & 0.000 \\
\hline & $P_{t}$ & -2.919 & 2.031 & 0.399 \\
\hline & $P_{a}$ & -3.912 & 2.878 & 0.023 \\
\hline \multirow[t]{4}{*}{ (5) } & $G_{t}$ & -4.829 & -3.612 & 0.000 \\
\hline & $G_{a}$ & -4.122 & 2.223 & 0.024 \\
\hline & $P_{t}$ & -3.828 & 2.459 & 0.019 \\
\hline & $P_{a}$ & -4.221 & -4.002 & 0.000 \\
\hline \multirow[t]{4}{*}{ (6) } & $G_{t}$ & -4.824 & -2.423 & 0.012 \\
\hline & $G_{a}$ & -4.900 & 2.001 & 0.051 \\
\hline & $P_{t}$ & -4.212 & 3.081 & 0.033 \\
\hline & $P_{a}$ & -1.896 & 2.104 & 0.203 \\
\hline
\end{tabular}

The optimal lags are based on SIC

put forward by Wang and Han (2016) for China and partially to the results presented by Samargandi (2019) for the members of the OPEC. On the other hand, the positive correlation between ICT-trade openness and energy efficiency, at substantially higher degrees of ICT-trade openness, corroborates with the views of Voigt et al. (2014) and Murshed (2019).

Among the other determinants of energy efficiency, per capita $\mathrm{CO}_{2}$ emissions are found to reduce the intensities of energy use in the South Asian economies. This could be understood in the sense that rising $\mathrm{CO}_{2}$ emission in the atmosphere is likely to trigger energy-saving behavior among the end-users of energy resources whereby more emphasis on energy conservation and fewer volumes of energy wastage can be expected. In contrast, incoming foreign remittances are likely to deteriorate energy efficiencies in the South Asian countries of concern. A $1 \%$ rise in foreign remittances is found to increase the intensities of energy use by $0.07-0.18 \%$, on average, ceteris paribus; thus, implicating energy efficiency losses. A particular reason behind this concerning finding could be that the remitted funds could drive up the overall energy demand among the households of the foreign migrators which, in turn, could elevate the intensity of energy use across the South Asian economies. As far as the impacts of economic growth are concerned, the elasticity estimates show that at lower levels, economic growth attributes to higher intensities of energy use. Hence, it can be said that in the short run, economic growth reduces the energy efficiency levels within the South Asian economies. This finding contradicts the short-run results in this regard in the context of the OPEC by Samargandi (2019). However, the long-run elasticity estimates in this paper reveal that in the latter growth phases, the impacts of growth on the energy intensities become inconclusive which can be perceived from the statistical insignificance of the corresponding elasticity parameters attached to the squared terms of GNIPC.

The long-run elasticity estimates in the context of model (4) are reported in Table 6. It is evident from the positive signs and statistical significance of the estimated elasticity parameters attached to ICT-trade openness and its squared term that liberalization of the barriers to trade of ICT goods significantly enhances the access to cleaner cooking fuels and technologies across the South Asian economies. More importantly, it is to be noted that these favorable impacts seem to increase monotonically along with persistent rises in the ICT-trade openness indices. This is a critically important finding especially in the context of rural regions across the South Asian economies that have predominantly been preoccupied with the use of the traditional biomass, agricultural residues, and other solid cooking fuels. Combustion of these relatively unclean cooking fuels has not only deteriorated the environmental balance but has also resulted in health adversities among the rural women in particular. Thus, the trade of ICT could be ideal in developing the energy infrastructure to facilitate the transmission and distribution of cleaner cooking fuels such as LPG. Hence, these findings support the conclusions made by Acharya and Marhold (2019) concerning cooking fuel transition in Nepal.

Besides, access to cleaner cooking fuels and technology is also found to be positively influenced by rising volumes of $\mathrm{CO}_{2}$ emissions across South Asia. The corresponding elasticity estimates denote that a rise in per capita $\mathrm{CO}_{2}$ emissions by $1 \%$ leads to a rise in the access to cleaner cooking fuels and technology by $6.75-9.10 \%$, on average, ceteris paribus. This implicates that apprehensions concerning higher emissions of $\mathrm{CO}_{2}$ are not only responsible for inducing RET within the South Asian economies, but such anxieties also stimulate the transition from the use of the traditional unclean to the modern cleaner cooking fuel alternatives. This is a realistic finding since the burning of the traditionally used solid cooking fuels are prime sources of black carbon emission-induced climate change adversities (UNEP and WMO 2011) and acute health issues (WHO 2012). As a result, rising emissions in this regard can be a stimulus for inducing the cleaner cooking fuel transition behaviors among the end-users. Similarly, higher rates of secondary school enrolment are seen to enhance greater access to cleaner cooking fuels and technology. Therefore, this finding establishes the importance of education with respect to awareness building in the context of understanding the adverse impacts of using conventional unclean cooking fuels. Better 
Table 5 The long-run elasticity estimates in context of models (1), (2), and (3)

\begin{tabular}{|c|c|c|c|c|c|c|c|c|c|}
\hline Model & (1) & (1) & (1) & (2) & (2) & (2) & (3) & (3) & (3) \\
\hline Dep. var. & $\ln R E C$ & $\ln R E C$ & $\ln R E C$ & lnRES & lnRES & lnRES & $\operatorname{lnEI}$ & $\ln E I$ & $\operatorname{lnEI}$ \\
\hline Estimator & CUP-FM & CUP-BC & FGLS & CUP-FM & CUP-BC & FGLS & CUP-FM & CUP-BC & FGLS \\
\hline \multicolumn{10}{|c|}{ Regressors } \\
\hline \multirow[t]{2}{*}{ lnIOPEN } & $0.446 * * *$ & $0.515 * *$ & $0.402 * * *$ & $-2.224 * *$ & $-1.897 * * *$ & $-0.803 * * *$ & $0.258 * * *$ & $0.496 * * *$ & $0.266 * *$ \\
\hline & $(0.092)$ & $(0.192)$ & $(0.086)$ & (1.104) & $(0.197)$ & $(0.019)$ & $(0.014)$ & $(0.093)$ & $(0.133)$ \\
\hline \multirow[t]{2}{*}{$\operatorname{lnIOPEN}^{2}$} & $0.855^{* * *}$ & $0.879 * * *$ & $0.736 * * *$ & $0.181^{* *}$ & $0.149^{* *}$ & $0.116^{* * *}$ & $-0.065 * * *$ & $-0.057 * * *$ & $-0.032 * *$ \\
\hline & $(0.011)$ & $(0.032)$ & $(0.015)$ & $(0.090)$ & $(0.073)$ & $(0.028)$ & $(0.014)$ & $(0.016)$ & $(0.016)$ \\
\hline \multirow[t]{2}{*}{$\operatorname{lnCO} 2$} & $0.084 * *$ & $0.130 * *$ & $0.102 * *$ & $3.474 * * *$ & $3.179 * * *$ & $2.991 * *$ & $-0.281 * * *$ & $-0.214 * * *$ & $-0.138 * *$ \\
\hline & $(0.037)$ & $(0.067)$ & $(0.053)$ & (1.316) & (1.006) & (1.277) & $(0.034)$ & $(0.025)$ & $(0.070)$ \\
\hline \multirow[t]{2}{*}{$\operatorname{lnOIL}$} & $-0.073 * *$ & $-0.071 * *$ & $-0.051 * * *$ & $-1.151 * * *$ & $-1.135^{* *}$ & $-1.147 * * *$ & -0.121 & -0.129 & -0.143 \\
\hline & $(0.038)$ & $(0.036)$ & $(0.015)$ & $(0.418)$ & $(0.651)$ & $(0.188)$ & $(0.122)$ & $(0.133)$ & $(0.121)$ \\
\hline \multirow[t]{2}{*}{$\operatorname{lnOIL}^{2}$} & $0.478 * *$ & $0.454 * *$ & $0.278 * * *$ & $2.955 * * *$ & $2.535^{*} * *$ & $2.447 * * *$ & -0.396 & -0.329 & -0.343 \\
\hline & $(0.074)$ & $(0.159)$ & $(0.085)$ & (1.018) & (1.012) & (1.188) & $(0.268)$ & $(0.315)$ & $(0.321)$ \\
\hline \multirow[t]{2}{*}{$\operatorname{lnFDI}$} & $-0.063 *$ & $-0.368 * * *$ & $-0.196^{* * *}$ & $-6.583 * * *$ & $-6.375^{* * *}$ & $-5.116^{* * *}$ & 0.051 & 0.141 & 0.056 \\
\hline & $(0.036)$ & $(0.056)$ & $(0.051)$ & $(0.477)$ & $(0.921)$ & (2.004) & $(0.033)$ & $(0.150)$ & $(0.031)$ \\
\hline \multirow[t]{2}{*}{$\operatorname{lnNODA}$} & $-0.253 * * *$ & $-0.125 * * *$ & $-0.150 * * *$ & $-8.189 * * *$ & $-6.528 * * *$ & $-9.193 * * *$ & -0.029 & -0.027 & -0.093 \\
\hline & $(0.068)$ & $(0.012)$ & $(0.006)$ & (2.147) & (2.939) & (2.313) & $(0.062)$ & $(0.075)$ & $(0.078)$ \\
\hline \multirow[t]{2}{*}{ lnREMIT } & $0.402 * * *$ & $0.415 * * *$ & $0.413 * * *$ & $11.53^{* * *}$ & $10.45 * * *$ & $10.47 * * *$ & $0.180 * * *$ & $0.091 * * *$ & $0.068 * * *$ \\
\hline & $(0.028)$ & $(0.063)$ & $(0.0271)$ & $(0.972)$ & (1.142) & (0.899) & $(0.026)$ & $(0.014)$ & $(0.015)$ \\
\hline \multirow[t]{2}{*}{$\operatorname{lnGNIPC}$} & $-0.237 * * *$ & $-0.175^{* * *}$ & $-0.138^{* * *}$ & $-14.711 * * *$ & $-14.611 * * *$ & $-13.411 * * *$ & $0.770 * * *$ & $1.494 * * *$ & $1.417 * * *$ \\
\hline & $(0.083)$ & $(0.045)$ & $(0.012)$ & $(5.461)$ & $(5.971)$ & $(2.422)$ & $(0.264)$ & $(0.656)$ & $(0.494)$ \\
\hline \multirow[t]{2}{*}{$\operatorname{lnGNIPC}{ }^{2}$} & $4.595 * * *$ & $2.323 * * *$ & $2.019 * * *$ & $-6.256^{* * *}$ & $-0.793 * * *$ & $-2.678 * * *$ & -0.012 & -0.068 & -0.059 \\
\hline & $(1.373)$ & $(0.430)$ & $(1.536)$ & (2.917) & $(0.230)$ & (1.334) & $(0.076)$ & $(0.052)$ & $(0.040)$ \\
\hline \multirow[t]{2}{*}{$\operatorname{lnCPI}$} & 0.006 & $0.042 * * *$ & $0.019 * *$ & 0.396 & 0.365 & 0.355 & 0.004 & -0.002 & -0.005 \\
\hline & $(0.008)$ & $(0.001)$ & $(0.008)$ & $(0.294)$ & $(0.273)$ & $(0.285)$ & $(0.008)$ & $(0.004)$ & $(0.003)$ \\
\hline \multirow[t]{2}{*}{ Constant } & $27.281 * * *$ & $12.325 * * *$ & $11.515^{*}$ & $183.1 * * *$ & $121.511 * * *$ & $121.911 * * *$ & $-4.800 * * *$ & $-5.311^{*}$ & $-6.00 * * *$ \\
\hline & $(5.375)$ & $(2.871)$ & $(6.250)$ & $(59.115)$ & (28.190) & $(16.122)$ & (1.947) & $(2.687)$ & (1.929) \\
\hline Wald $\mathrm{Chi}^{2}$ & & & $2114.1 * * *$ & & & $1419.2 * * *$ & & & $2655^{* * *}$ \\
\hline Adj. $R^{2}$ & 0.799 & 0.816 & & 0.726 & 0.793 & & 0.756 & 0.756 & \\
\hline Observations & 101 & 101 & 102 & 101 & 101 & 102 & 101 & 101 & 102 \\
\hline
\end{tabular}

The standard errors are reported within the parentheses; $* * *, * *$, and $*$ denote statistical significance at $1 \%, 5 \%$, and $10 \%$ levels respectively

awareness in this regard is acknowledged in the literature to induce the substitution of these cooking fuels by the relatively cleaner alternatives. This result is parallel to the identical findings reported by Murshed (2018). Finally, the elasticity estimates denote that economic growth monotonically enhances access to cleaner cooking fuels and technology. The magnitudes of the predicted elasticity parameters attached to the squared term of GNIPC are higher than the parameters attached to GNIPC. These collectively imply that access to relatively cleaner cooking fuels tends to keep increasing alongside the growth of the South Asian economies. This could be due to the fact that as a nation develops, it gets empowered enough to overcome the factors that inhibit the prospects of enhancing access to cleaner cooking fuels across South Asia.

It is evident from the aforementioned regression findings that ICT trade plays a crucial role in facilitating RET, improving energy efficiency levels, and stimulating adoption of the cleaner cooking fuels across South Asia. However, ICT, apart from diminishing $\mathrm{CO}_{2}$ emissions directly, can also be tapped to mitigate $\mathrm{CO}_{2}$ emissions indirectly through these channels. Hence, both the conditional direct and indirect impacts of ICT-trade openness on $\mathrm{CO}_{2}$ emissions are assessed. Table 7 reports the long-run elasticity estimates in the context of models 5 and 6 . The elasticities denote that ICT trade, in general, deteriorates environmental quality across the selected South Asian economies, which is evident from the positive signs of the statistically significant elasticity parameters attached to ICT-trade openness and its squared term. However, the magnitude of the elasticity parameter attached to the squared term is relatively smaller, thus, indicating that the adverse impacts of liberalizing ICT trade barriers on $\mathrm{CO}_{2}$ emissions tend to cease along with persistent enhancement of the ICT-trade openness indices. This implies that initially the penetration of ICT goods, in the form of ICT imports in particular, into the concerned South Asian 
economies is likely to boost the energy consumption levels, especially the NRE resources, whereby higher emissions of $\mathrm{CO}_{2}$ can be rationalized. However, with greater trade of ICT commodities and gradual development of the ICT sector within these economies, the trend can be anticipated to reverse, thus, mitigating the $\mathrm{CO}_{2}$ emissions in the long-run. The lagged favorable impacts of ICT penetration with respect to mitigating $\mathrm{CO}_{2}$ emissions were also concluded by Asongu et al. (2018) for Sub-Saharan African countries while Faisal et al. (2020) opined made similar remarks in the context of Brazil, India, China, and South Africa. Similar conclusions were made by Shafiei and Salim (2014) for the OECD economies.

On the other hand, the statistical significance of the interaction terms of REC and NREC with IOPEN implicates the joint impacts of ICT trade and energy consumption on $\mathrm{CO}_{2}$ emissions. Once again, the heterogeneity of the joint impacts can be observed. The elasticity estimates show that ICT trade and RE consumption jointly accounts for lower $\mathrm{CO}_{2}$ emissions while

Table 6 The long-run elasticity estimates in context of models (4)

\begin{tabular}{|c|c|c|c|}
\hline Model & (4) & (4) & (4) \\
\hline Dep. var. & $\ln \mathrm{ACFT}$ & $\ln \mathrm{ACFT}$ & $\ln \mathrm{ACFT}$ \\
\hline Estimator & CUP-FM & CUP-BC & FGLS \\
\hline \multicolumn{4}{|l|}{ Regressors } \\
\hline \multirow[t]{2}{*}{ lnIOPEN } & $3.728 * * *$ & $1.897 * * *$ & $2.480 * * *$ \\
\hline & (1.133) & $(0.435)$ & $(1.001)$ \\
\hline \multirow[t]{2}{*}{$\operatorname{lnIOPEN}^{2}$} & $7.061 * * *$ & $6.591 * * *$ & $7.925 * * *$ \\
\hline & $(1.596)$ & $(2.296)$ & $(2.830)$ \\
\hline \multirow[t]{2}{*}{$\operatorname{lnCO}{ }_{2}$} & $9.101 * * *$ & $8.617 * * *$ & $6.753 * * *$ \\
\hline & (3.793) & (2.409) & $(2.975)$ \\
\hline \multirow[t]{2}{*}{$\operatorname{lnOIL}$} & 1.894 & 1.536 & 1.129 \\
\hline & (1.544) & $(1.268)$ & (1.048) \\
\hline \multirow[t]{2}{*}{$\operatorname{lnOIL}{ }^{2}$} & 4.094 & 3.536 & 2.129 \\
\hline & $(2.744)$ & $(2.668)$ & (2.348) \\
\hline \multirow[t]{2}{*}{$\operatorname{lnLIFE}$} & 2.249 & 1.893 & 1.238 \\
\hline & (1.982) & (1.590) & (1.090) \\
\hline \multirow[t]{2}{*}{$\operatorname{lnSSE}$} & $2.853 * * *$ & $1.831 * *$ & $1.626^{* * *}$ \\
\hline & $(0.649)$ & $(0.935)$ & $(0.224)$ \\
\hline \multirow[t]{2}{*}{$\operatorname{lnCPI}$} & -0.319 & -0.310 & -0.281 \\
\hline & $(0.212)$ & $(0.213)$ & $(0.199)$ \\
\hline \multirow[t]{2}{*}{$\operatorname{lnGNIPC}$} & $3.349 * * *$ & $3.453 * * *$ & $3.386^{* * *}$ \\
\hline & (1.180) & (1.197) & $(1.202)$ \\
\hline \multirow[t]{2}{*}{$\operatorname{lnGNIPC}{ }^{2}$} & $8.141 * * *$ & $8.053 * * *$ & $8.189^{* * *}$ \\
\hline & $(2.322)$ & (2.956) & (2.618) \\
\hline \multirow[t]{2}{*}{ Constant } & $-51.179 * * *$ & $-15.332 * *$ & $-52.157 * * *$ \\
\hline & (20.048) & (7.688) & (16.0594) \\
\hline Wald $\mathrm{Chi}^{2}$ & & & $1223.1 * * *$ \\
\hline Adj. $R^{2}$ & 0.641 & 0.762 & \\
\hline Observations & 101 & 101 & 102 \\
\hline
\end{tabular}

The standard errors are reported within the parentheses; ***, **, and * denote statistical significance at $1 \%, 5 \%$, and $10 \%$ levels respectively the joint impact of ICT trade and NRE consumption on $\mathrm{CO}_{2}$ emissions is found to be negative. Therefore, it can be said that ICT trade also has an indirect impact on environmental quality through its impacts on consumption RE and NRE resources. Consequently, it can be said that the liberalization of barriers to ICT trade is effective in reducing $\mathrm{CO}_{2}$ emissions provide the RE consumption levels are also boosted simultaneously. Besides, both higher energy use efficiencies and success to cleaner cooking fuels are found to be ideal in reducing the $\mathrm{CO}_{2}$ emissions. The corresponding elasticity estimates denote that $1 \%$ increases in the energy intensities and access to cleaner cooking fuels respectively increase per capita $\mathrm{CO}_{2}$ emissions by 1.13 $1.40 \%$ and decrease $\mathrm{CO}_{2}$ emissions, on average, ceteris paribus. Moreover, it can also be seen that ICT trade and energy intensity levels jointly boost $\mathrm{CO}_{2}$ emissions while similar $\mathrm{CO}_{2}$ mitigation impacts are also evident in the context of joint impacts of ICT trade and cleaner cooking fuel access. Therefore, these results once again endorse the indirect impacts of ICT trade on $\mathrm{CO}_{2}$ emissions across the South Asian economies.

Among the other key determinant of $\mathrm{CO}_{2}$ emissions, rising crude oil prices are found to reduce the $\mathrm{CO}_{2}$ emission levels. A rise in the real price of crude oil reduces $0.16-0.44 \%$, on average, ceteris paribus. This could be due to higher oil prices having a dampening impact on demand and the use of crude oil whereby the volumes of $\mathrm{CO}_{2}$ emission can be expected to decline. The results are parallel to those found by Erdogan et al. (2020) for OECD counties. Also, the long-run elasticity estimates validate the EKC hypothesis in the context of the South Asian economies. The positive and negative signs of the estimated elasticity parameters attached to GNIPC and its squared terms, respectively, affirm this claim. It implies that during the initial stages of economic growth, there is a trade-off between economic and environmental welfare, thus growth accounts for higher $\mathrm{CO}_{2}$ emissions to deteriorate environmental quality. However, upon attainment of a significant amount of growth, the economyenvironment trade-off is alleviated whereby further economic growth attribute to lower $\mathrm{CO}_{2}$ emissions. Similar results were also found by Apergis and Ozturk (2015) and Apergis (2016).

Following the long-run elasticity estimations using the regression analysis, the Dumitrescu-Hurlin heterogeneous panel causality analysis is performed to unearth the possible directions of causality among the variables. The causal associations engulfing ICT trade, reported in Tables 8 and 9, show that liberalization of barriers impeding ICT trade has causal influences on RE consumption levels, RE shares in aggregate final energy consumption figures, energy efficiency levels, access to cleaner cooking fuels, and $\mathrm{CO} 2$ emissions. The results show that unidirectional causations, without the feedback, stem from ICT-trade openness to RE consumption, intensities of energy use, and cleaner cooking fuel access. Hence, these causal estimates, together with the corresponding long-run elasticity estimates explained earlier, highlight the significance of relaxing trade barriers associated with cross-border flows of ICT goods. 
On the other hand, the results also confirm bidirectional causations between ICT-trade openness and RE shares and also between ICT-trade openness and $\mathrm{CO}_{2}$ emissions. Therefore, these feedback relationships suggest that ICT trade causes RET and environmental quality improvement across the South Asian countries but the transition from NRE to RE use and lower $\mathrm{CO}_{2}$ emissions are also responsible for higher volumes of ICT trade in the future. For instance, low RE shares, attributing to energy insecurity and other health and environmental issues, could trigger the need for technological innovations across the South Asian economies whereby the demand for ICT commodities can go up. Since the South Asian economies have traditionally been net-importers of ICT, there could be pressures to reduce the barriers impeding ICT imports, thus, consequently enforcing lower tariffs in the regard. As a result, the ICT-trade openness indices can be expected to go up. On the other hand, apprehensions concerning aggravation of $\mathrm{CO}_{2}$ emission levels can also induce a behavioral change in respect of energy conservation and also spark the need for undergoing RET across South Asia. This, in turn, would require the development of the ICT sector which can possibly uplift the demand for ICT within the concerned South Asian economies. As a consequence, the ICT-trade openness indices can once again be anticipated to rise.
Table 7 The long-run elasticity estimates in context of models (5) and (6)

\begin{tabular}{|c|c|c|c|c|c|c|}
\hline Model & (5) & (5) & (5) & (6) & (6) & (6) \\
\hline Dep. var. & $\operatorname{lnCO} 2$ & $\operatorname{lnCO} 2$ & $\operatorname{lnCO} 2$ & $\operatorname{lnCO} 2$ & $\operatorname{lnCO} 2$ & $\operatorname{lnCO} 2$ \\
\hline Estimator & CUP-FM & CUP-BC & FGLS & CUP-FM & CUP-BC & GFLS \\
\hline \multicolumn{7}{|l|}{ Regressors } \\
\hline \multirow[t]{2}{*}{ lnIOPEN } & $0.414 * * *$ & $0.456^{* *}$ & $0.391 * * *$ & $0.460 * * *$ & $0.517 * * *$ & $0.474 * * *$ \\
\hline & $(0.153)$ & $(0.230)$ & $(0.101)$ & $(0.059)$ & $(0.019)$ & $(0.049)$ \\
\hline \multirow[t]{2}{*}{$\operatorname{lnIOPEN}{ }^{2}$} & $0.232 * *$ & $0.186^{* *}$ & $0.147 * * *$ & $0.038 * *$ & $0.021 * *$ & $0.041 * * *$ \\
\hline & $(0.115)$ & $(0.0676)$ & $(0.036)$ & $(0.013)$ & $(0.010)$ & $(0.011)$ \\
\hline \multirow[t]{2}{*}{$\operatorname{lnREC}$} & $-2.041 * * *$ & $-2.157 * * *$ & $-2.334 * * *$ & & & \\
\hline & $(1.055)$ & $(0.038)$ & $(0.109)$ & & & \\
\hline \multirow[t]{2}{*}{ 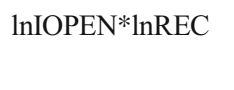 } & $-0.491 * *$ & $-0.443 * * *$ & $-0.385 * * *$ & & & \\
\hline & $(0.241)$ & $(0.121)$ & $(0.062)$ & & & \\
\hline \multirow[t]{2}{*}{ lnNREC } & & & & $3.176 * * *$ & $3.529 * * *$ & $4.170 * * *$ \\
\hline & & & & $(0.075)$ & $(0.061)$ & $(0.033)$ \\
\hline \multirow[t]{2}{*}{ lnIOPEN*NREC } & & & & $0.359 * * *$ & $0.224 * *$ & $0.192 * * *$ \\
\hline & & & & $(0.137)$ & $(0.111)$ & $(0.046)$ \\
\hline \multirow[t]{2}{*}{$\operatorname{lnEI}$} & $1.129 * * *$ & $1.332 * * *$ & $1.401 * *$ & & & \\
\hline & $(0.391)$ & $(0.400)$ & $(0.689)$ & & & \\
\hline \multirow[t]{2}{*}{ 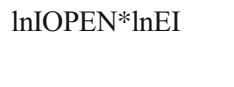 } & $-0.129 * *$ & $-0.133 * *$ & $-0.102 * * *$ & & & \\
\hline & $(0.062)$ & $(0.065)$ & $(0.029)$ & & & \\
\hline \multirow[t]{2}{*}{$\ln \mathrm{ACFT}$} & & & & $0.308 * * *$ & $0.332 * * *$ & $0.391 * * *$ \\
\hline & & & & $(0.102)$ & $(0.121)$ & $(0.117)$ \\
\hline \multirow[t]{2}{*}{ lnIOPEN*lnACFT } & & & & $-0.021 * *$ & $-0.028 * *$ & $-0.032 * * *$ \\
\hline & & & & $(0.009)$ & $(0.015)$ & $(0.010)$ \\
\hline \multirow[t]{2}{*}{$\operatorname{lnOIL}$} & $-0.177 * *$ & $-0.118^{* *}$ & $-0.159 * *$ & $-0.444 * * *$ & $-0.158 * *$ & $-0.141 * * *$ \\
\hline & $(0.081)$ & $(0.056)$ & $(0.079)$ & $(0.113)$ & $(0.078)$ & $(0.049)$ \\
\hline \multirow[t]{2}{*}{ lnGNIPC } & $406.73 * * *$ & 403.851 *** & $384.84 * * *$ & $39.175 * * *$ & $29.922 * * *$ & $41.891 * * *$ \\
\hline & $(29.810)$ & $(28.944)$ & $(23.052)$ & $(12.805)$ & (13.149) & (12.599) \\
\hline \multirow[t]{2}{*}{$\operatorname{lnGNIPC} 2$} & $-2.634 * * *$ & $-2.623 * * *$ & $-2.669 * * *$ & $-1.377 * * *$ & $-1.194 * *$ & $-1.263 * * *$ \\
\hline & $(0.600)$ & $(0.541)$ & $(0.187)$ & (0.109) & $(0.367)$ & $(0.360)$ \\
\hline \multirow[t]{2}{*}{ Constant } & $-0.986 * * *$ & $-0.992 * *$ & $-1.012^{* *}$ & $-0.179 * * *$ & $-0.158 * * *$ & $-0.182 * * *$ \\
\hline & $(0.014)$ & $(0.482)$ & $(0.507)$ & $(0.003)$ & $(0.002)$ & $(0.004)$ \\
\hline Wald $\mathrm{Chi}^{2}$ & & & $1293 * * *$ & & & $4634 * * *$ \\
\hline Adj. $R^{2}$ & 0.729 & 0.712 & & 0.785 & 0.763 & \\
\hline Observations & 101 & 101 & 102 & 101 & 101 & 102 \\
\hline
\end{tabular}

The standard errors are reported within the parentheses; $* * *, * *$, and $*$ denote statistical significance at $1 \%, 5 \%$, and $10 \%$ levels respectively 
Table 8 Dumitrescu and Hurlin (2012) heterogeneous panel causality test results

\begin{tabular}{|c|c|c|c|c|c|c|c|c|}
\hline \multicolumn{3}{|l|}{ Model (1) } & \multicolumn{3}{|l|}{ Model (2) } & \multicolumn{3}{|l|}{ Model (3) } \\
\hline $\begin{array}{l}\text { Dep. } \\
\text { var. }\end{array}$ & $\begin{array}{l}\text { Indep. } \\
\text { var. }\end{array}$ & $Z$-stat & $\begin{array}{l}\text { Dep. } \\
\text { var. }\end{array}$ & $\begin{array}{l}\text { Indep. } \\
\text { var. }\end{array}$ & $Z$-stat & $\begin{array}{l}\text { Dep. } \\
\text { var. }\end{array}$ & $\begin{array}{l}\text { Indep. } \\
\text { var. }\end{array}$ & $Z$-stat \\
\hline $\operatorname{lnREC}$ & lnIOPEN & $5.371 * * *$ & $\operatorname{lnRES}$ & lnIOPEN & $5.471 * * *$ & $\ln \ln E I$ & lnIOPEN & $3.438^{* * *}$ \\
\hline InIOPEN & $\operatorname{lnREC}$ & -0.068 & lnIOPEN & $\operatorname{lnRES}$ & $4.211 * * *$ & lnIOPEN & $\operatorname{lnEI}$ & 0.582 \\
\hline $\operatorname{lnREC}$ & $\operatorname{lnCO} \mathrm{O}_{2}$ & $3.323 * * *$ & $\operatorname{lnRES}$ & $\operatorname{lnCO} 2$ & $7.626^{* * * *}$ & $\operatorname{lnEI}$ & $\operatorname{lnCO} 2$ & 0.189 \\
\hline $\operatorname{lnCO} 2$ & $\operatorname{lnREC}$ & 0.275 & $\operatorname{lnCO} 2$ & $\operatorname{lnRES}$ & 1.335 & $\operatorname{lnCO} 2$ & $\operatorname{lnEI}$ & $2.712 * * *$ \\
\hline $\operatorname{lnREC}$ & $\operatorname{lnOIL}$ & $3.140 * * *$ & $\operatorname{lnRES}$ & $\operatorname{lnOIL}$ & $6.684 * * *$ & $\operatorname{lnEI}$ & $\operatorname{lnOIL}$ & $5.103 * * *$ \\
\hline $\operatorname{lnOIL}$ & $\operatorname{lnREC}$ & 0.638 & $\operatorname{lnOIL}$ & $\operatorname{lnRES}$ & -1.241 & $\operatorname{lnOIL}$ & $\operatorname{lnEI}$ & 0.503 \\
\hline $\operatorname{lnREC}$ & $\operatorname{lnFDI}$ & -0.052 & $\operatorname{lnRES}$ & $\operatorname{lnFDI}$ & $2.774 * * *$ & $\operatorname{lnEI}$ & $\operatorname{lnFDI}$ & 0.386 \\
\hline $\operatorname{lnFDI}$ & $\operatorname{lnREC}$ & 0.869 & $\operatorname{lnFDI}$ & $\operatorname{lnRES}$ & $2.285^{* *}$ & $\operatorname{lnFDI}$ & $\operatorname{lnEI}$ & $4.720 * * *$ \\
\hline $\operatorname{lnREC}$ & $\operatorname{lnODA}$ & $2.248 * *$ & $\operatorname{lnRES}$ & $\operatorname{lnNODA}$ & $3.541 * * *$ & $\ln E I$ & lnNODA & 1.298 \\
\hline $\operatorname{lnNODA}$ & $\ln R E C$ & $4.492 * * *$ & $\operatorname{lnNODA}$ & $\operatorname{lnRES}$ & $6.311 * * *$ & $\operatorname{lnNODA}$ & $\operatorname{lnEI}$ & 7.454 \\
\hline $\operatorname{lnREC}$ & $\operatorname{lnREMIT}$ & $6.003 * * *$ & $\operatorname{lnRES}$ & InREMIT & $7.786^{* * *}$ & $\operatorname{lnEI}$ & InREMIT & $1.97 * *$ \\
\hline $\operatorname{lnREMIT}$ & $\operatorname{lnREC}$ & $19.956 * * *$ & lnREMIT & lnRES & 1.357 & lnREMIT & $\operatorname{lnEI}$ & $22.08 * * *$ \\
\hline $\operatorname{lnREC}$ & $\operatorname{lnGNIPC}$ & $8.268 * * *$ & $\operatorname{lnRES}$ & lnGNIPC & $2.69 *$ & $\operatorname{lnEI}$ & $\operatorname{lnGNIPC}$ & $6.567 * * *$ \\
\hline $\operatorname{lnGNIPC}$ & $\operatorname{lnREC}$ & 1.052 & $\operatorname{lnGNIPC}$ & $\operatorname{lnRES}$ & $3.101^{*} * *$ & $\operatorname{lnGNIPC}$ & $\ln E I$ & 1.510 \\
\hline $\ln R E C$ & $\operatorname{lnCPI}$ & 1.501 & $\operatorname{lnRES}$ & $\operatorname{lnCPI}$ & $1.91 *$ & $\operatorname{lnEI}$ & $\operatorname{lnCPI}$ & -1.031 \\
\hline $\operatorname{lnCPI}$ & $\operatorname{lnREC}$ & 0.311 & $\operatorname{lnCPI}$ & $\operatorname{lnRES}$ & -0.096 & $\operatorname{lnCPI}$ & $\operatorname{lnEI}$ & 0.617 \\
\hline
\end{tabular}

The estimated $Z$-statistics are reported; ***, **, and * denote statistical significance at $1 \%, 5 \%$, and $10 \%$ levels respectively

Besides, the causality estimates presented in Table 9 reveal that there is bidirectional causation between $\mathrm{RE}$ consumption and $\mathrm{CO}_{2}$ emissions. This is a key finding in the context of South Asia since most of the South Asian economies are predominantly intensive in NRE use and are also polluted to a large extent. Thus, undergoing RET is a bare requirement for these economies. Thus, this bidirectional causal nexus between $\mathrm{RE}$ consumption and $\mathrm{CO}_{2}$ emissions, in this regard, could be encouraging in the sense that the dismal state of environmental quality across the majority of the South Asian economies, India in particular, could trigger the adoption of $\mathrm{RE}$ technologies which in turn could safeguard these nations against the vulnerabilities concerning the $\mathrm{CO}_{2}$ emissioninduced climate change adversities. A similar bidirectional causal association between RE consumption and $\mathrm{CO}_{2}$ emissions was highlighted by Apergis and Payne (2015) for South American economies. Other key causality findings include the existence of unidirectional causations running from

Table 9 Dumitrescu and Hurlin (2012) heterogeneous panel causality test results

\begin{tabular}{|c|c|c|c|c|c|}
\hline \multicolumn{3}{|l|}{ Model (4) } & \multicolumn{3}{|c|}{ Models (5) and (6) } \\
\hline Dep. var. & Indep. var. & $Z$-stat & Dep. var. & Indep. var. & $Z$-stat \\
\hline $\ln \mathrm{ACFT}$ & lnIOPEN & $5.428 * * *$ & $\operatorname{lnCO} 2$ & lnIOPEN & $8.031 * * *$ \\
\hline lnIOPEN & $\ln \mathrm{ACFT}$ & 1.150 & lnIOPEN & $\operatorname{lnCO} 2$ & $2.012 * *$ \\
\hline $\ln \mathrm{ACF}$ & $\operatorname{lnCO} 2$ & -0.715 & $\operatorname{lnCO} 2$ & $\ln R E C$ & $4.275 * * *$ \\
\hline $\operatorname{lnCO} 2$ & $\ln \mathrm{ACFT}$ & $3.755 * * *$ & $\operatorname{lnREC}$ & $\operatorname{lnCO} 2$ & $3.324 * * *$ \\
\hline $\ln \mathrm{ACFT}$ & $\operatorname{lnOIL}$ & -0.401 & $\ln \mathrm{CO}_{2}$ & lnNREC & $8.191 * * *$ \\
\hline $\operatorname{lnOIL}$ & $\ln \mathrm{ACFT}$ & -0.464 & lnNREC & $\operatorname{lnCO} 2$ & $13.272 * * *$ \\
\hline $\ln \mathrm{ACFT}$ & $\operatorname{lnLIFE}$ & -0.001 & $\operatorname{lnCO} 2$ & $\ln E I$ & $7.123 * * *$ \\
\hline $\operatorname{lnLIFE}$ & $\ln \mathrm{ACFT}$ & $271.48 * * *$ & $\ln E I$ & $\operatorname{lnCO} 2$ & 1.223 \\
\hline $\ln \mathrm{ACFT}$ & $\operatorname{lnSSE}$ & 0.001 & $\operatorname{lnCO} 2$ & $\ln \mathrm{ACFT}$ & $8.448 * * *$ \\
\hline $\operatorname{lnSSE}$ & $\operatorname{lnACFT}$ & 0.129 & $\operatorname{lnACFT}$ & $\operatorname{lnCO} 2$ & 1.229 \\
\hline $\operatorname{lnACFT}$ & $\operatorname{lnCPI}$ & $3.453 * * *$ & $\operatorname{lnCO} 2$ & $\operatorname{lnOIL}$ & $2.119 * *$ \\
\hline $\operatorname{lnCPI}$ & $\ln \mathrm{ACFT}$ & -1.023 & $\operatorname{lnOIL}$ & $\operatorname{lnCO} 2$ & -1.041 \\
\hline $\operatorname{lnACFT}$ & $\operatorname{lnGNIPC}$ & -0.177 & $\operatorname{lnCO} 2$ & $\operatorname{lnGNIPC}$ & $4.848 * * *$ \\
\hline $\operatorname{lnGNIPC}$ & $\ln \mathrm{ACFT}$ & 2.595 & $\operatorname{lnGNIPC}$ & $\operatorname{lnCO} 2$ & $3.665 * * *$ \\
\hline
\end{tabular}

The estimated $Z$-statistics are reported; $* * *$ and $* *$ denote statistical significance at $1 \%$ and $5 \%$ levels respectively 
energy efficiency levels and access to cleaner cooking fuels to $\mathrm{CO}_{2}$ emissions. Hence, in line with the corresponding regression findings explained earlier, these unidirectional causalities further emphasize the roles of improving energy use efficiencies and transitioning to use of cleaner cooking fuels, preferably through ICT development, with respect to reducing $\mathrm{CO}_{2}$ emissions in South Asia. In contrast to the unidirectional causation from energy efficiencies to $\mathrm{CO}_{2}$ emissions found in this paper, Hatzigeorgiou et al. (2011) in the context of Greece.

For the comparability of the causal findings across different methods for estimating causation using panel data, the Granger (1969) and the Geweke (1982) causality techniques are applied. The corresponding results from these test, as reported in Tables 10,11, 12, and 13 in the Appendix, show that these techniques are inferior compared to the Dumitrescu-Hurlin causality estimation method since the test statistics concerning these methods fail to statistically establish causal linkages between the concerned variables in most of the cases.

\section{Conclusion}

Ensuring energy security and environmental sustainability has gradually become a core concern across the globe whereby the global economic growth policies, from a more comprehensive perspective, are gradually being aligned with complementary strategies that simultaneously safeguard the reliable supply of energy resources and also improve the overall quality of the world environment. More often than not, technological innovation is a pre-requisite for the attainment of these aforementioned multidimensional growth policies. Given the vast divide in respect of technological advancement between the first and the third world countries, implementation of such comprehensive growth policies becomes relatively cumbersome for the developing economies; courtesy of technological constraints faced. Against this backdrop, this paper attempted to reason the justification behind the liberalization of barriers to ICT trade for ensuring energy security and environmental sustainability across selected South Asian economies: Bangladesh, India, Pakistan, Sri Lanka, Nepal, and Maldives. The overall findings from the econometric analyses, in a nutshell, reveal two crucial findings. First, enhancing ICT-trade openness is found to exert direct impacts to facilitate RET, improve energy use efficiencies, enhance access to cleaner cooking fuels and technologies, and reduce $\mathrm{CO}_{2}$ emissions. The associated relationships are mostly non-linear and also confirm the beneficial roles of enhancing ICT trade in this regard. Second, ICT trade also exhibits an indirect impact on reducing $\mathrm{CO} 2$ emissions through its direct impacts on RET, energy efficiency improvement, and enhanced access to cleaner cooking fuels. Besides, the results also led to the key finding that $\mathrm{CO}_{2}$ emissions across South Asia are conditional on the nature of the energy resources consumed since consumption of $\mathrm{RE}$ is found to curb the per capita $\mathrm{CO}_{2}$ emission levels while NRE consumption was seen to aggravate the emission further.

Therefore, in line with the overall findings from this paper, it is recommended that the governments of the concerned South Asian economies gradually liberalize the trade barriers that inhibit cross-border flows of ICT goods and services. Simultaneously, effective measures should be undertaken to incentivize the use of RE resources and reduce the predominant use of NRE. Moreover, since the impacts of ICT on $\mathrm{CO}_{2}$ emissions are found to be largely conditional on the types of energy resources consumed, liberalization of the barriers should be designed meticulously so that it favors trade of the relatively greener ICT commodities that have the capacity incorporating and operating on energy sourced from RE resources and are also comparatively energy-efficient which, in turn, could be credible means to safeguard both the energy security and environmental sustainability goals across South Asia. Besides, restructuring of the foreign investment policies should also be considered for attracting foreign direct investments into the ICT sectors of the South Asian economies which, in turn, would be effective in developing these sectors through a knowledge spillover effect associated with such foreign investments. Furthermore, decentralization of the existing energy systems in several of the South Asian economies, especially Bangladesh, whereby the use of ICT-enabled off-grid renewable electrification can be a solution to the low rural electrification rates across South Asia. In this regard, provision for the smartening of the existing grids and incentives through the use of ICT can also overcome the prevailing in-grid inefficiencies to reduce power transmission and distribution losses.

As part of the future scope of research, this analysis can be extended by further disaggregating ICT-trade openness in ICT commodity-specific openness to assess the potential heterogeneity of the impacts. It is pertinent to do so because although a plethora of the existing studies have probed into the impacts of ICT goods, especially Internet and mobile subscriptions on RET, energy efficiency and $\mathrm{CO}_{2}$ emissions, little is known in the context of the dynamic impacts associated with the liberalization of the barriers that restrict the trade of these key ICT goods. Besides, the incorporation of different energy resources and diverse indicators of environmental quality into the analysis would provide the overall robustness of the findings. Furthermore, this analysis of the impacts of ICT trade on energy security and environmental sustainability can also be performed for other regions and country-specific cases. 


\section{Appendix}

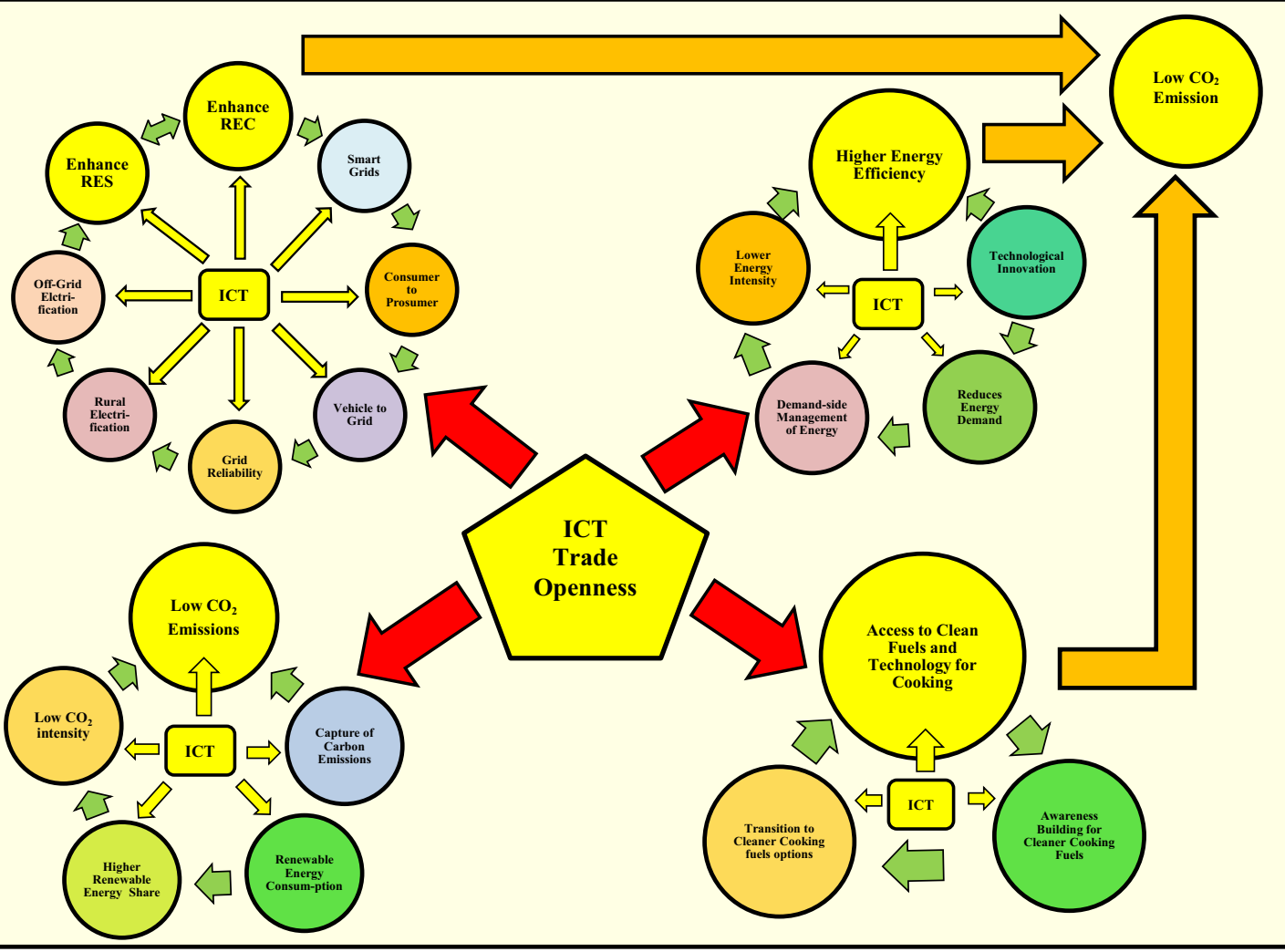

Fig. 6 ICT denotes Information and Communications Technology; REC and RES refer to renewable energy consumption and share of renewable energy in total final energy consumption, respectively; The red arrows denote the direct impacts of ICT trade on renewable energy transition, energy efficiency enhancement, greater access to cleaner cooking fuels, and lower $\mathrm{CO}_{2}$ emissions. The orange arrows denote the indirect impacts of ICT on $\mathrm{CO}_{2}$ emissions. The potential benefits of enhancing ICT trade for RET, energy efficiency, and environmental sustainability

Table 10 Panel Granger causality test results

\begin{tabular}{|c|c|c|c|c|c|c|c|c|}
\hline \multicolumn{3}{|l|}{ Model (1) } & \multicolumn{3}{|l|}{ Model (2) } & \multicolumn{3}{|l|}{ Model (3) } \\
\hline $\begin{array}{l}\text { Dep. } \\
\text { var. }\end{array}$ & $\begin{array}{l}\text { Indep. } \\
\text { var. }\end{array}$ & $\mathrm{Chi}^{2}$-stat & $\begin{array}{l}\text { Dep. } \\
\text { var. }\end{array}$ & $\begin{array}{l}\text { Indep. } \\
\text { var. }\end{array}$ & $\mathrm{Chi}^{2}$-stat & $\begin{array}{l}\text { Dep. } \\
\text { var. }\end{array}$ & $\begin{array}{l}\text { Indep. } \\
\text { var. }\end{array}$ & $\mathrm{Chi}^{2}$-stat \\
\hline $\operatorname{lnREC}$ & InIOPEN & $1.993 *$ & $\operatorname{lnRES}$ & lnIOPEN & 0.812 & $\operatorname{lnEI}$ & lnIOPEN & 1.985 \\
\hline lnIOPEN & $\operatorname{lnREC}$ & 1.239 & lnIOPEN & $\operatorname{lnRES}$ & 1.631 & lnIOPEN & $\operatorname{lnEI}$ & 4.153 \\
\hline $\operatorname{lnREC}$ & $\operatorname{lnCO} 2$ & 0.664 & $\operatorname{lnRES}$ & $\operatorname{lnCO^{2}}$ & $12.855 * * *$ & $\operatorname{lnEI}$ & $\operatorname{lnCO^{2}}$ & 1.954 \\
\hline $\operatorname{lnCO}{ }_{2}$ & $\operatorname{lnREC}$ & 1.267 & $\operatorname{lnCO}{ }_{2}$ & $\operatorname{lnRES}$ & 1.505 & $\operatorname{lnCO}{ }^{2}$ & $\operatorname{lnEI}$ & 0.885 \\
\hline $\operatorname{lnREC}$ & $\operatorname{lnOIL}$ & 0.427 & $\operatorname{lnRES}$ & $\operatorname{lnOIL}$ & $5.637 *$ & $\ln E I$ & $\operatorname{lnOIL}$ & $14.065 * * *$ \\
\hline $\operatorname{lnOIL}$ & $\operatorname{lnREC}$ & 0.286 & $\operatorname{lnOIL}$ & lnRES & 1.976 & $\operatorname{lnOIL}$ & $\operatorname{lnEI}$ & 0.194 \\
\hline $\operatorname{lnREC}$ & $\operatorname{lnFDI}$ & 0.086 & $\operatorname{lnRES}$ & $\operatorname{lnFDI}$ & $6.479 * *$ & $\ln E I$ & $\operatorname{lnFDI}$ & 0.546 \\
\hline $\operatorname{lnFDI}$ & $\operatorname{lnREC}$ & $11.657 * * *$ & $\operatorname{lnFDI}$ & lnRES & $9.489 * * *$ & $\operatorname{lnFDI}$ & $\operatorname{lnEI}$ & $12.757 * * *$ \\
\hline $\operatorname{lnREC}$ & $\operatorname{lnNODA}$ & 1.758 & $\operatorname{lnRES}$ & lnNODA & 2.563 & $\operatorname{lnEI}$ & lnNODA & 0.802 \\
\hline $\operatorname{lnNODA}$ & $\operatorname{lnREC}$ & 1.792 & $\operatorname{lnNODA}$ & $\operatorname{lnRES}$ & $6.661 *$ & $\operatorname{lnNODA}$ & $\operatorname{lnEI}$ & 1.929 \\
\hline $\operatorname{lnREC}$ & lnREMIT & 1.068 & $\operatorname{lnRES}$ & InREMIT & $6.585^{* *}$ & $\ln E I$ & lnREMIT & $4.588^{*}$ \\
\hline $\operatorname{lnREMIT}$ & $\operatorname{lnREC}$ & $16.449 * * *$ & $\operatorname{lnREMIT}$ & $\operatorname{lnRES}$ & $17 . * * *$ & $\operatorname{lnREMIT}$ & $\operatorname{lnEI}$ & 3.811 \\
\hline $\operatorname{lnREC}$ & $\operatorname{lnGNIPC}$ & 0.324 & $\operatorname{lnRES}$ & lnGNIPC & $9.750 * * *$ & $\ln E I$ & lnGNIPC & 2.743 \\
\hline $\operatorname{lnGNIPC}$ & $\operatorname{lnREC}$ & $3.129 * * *$ & $\operatorname{lnGNIPC}$ & $\operatorname{lnRES}$ & 0.525 & $\operatorname{lnGNIPC}$ & $\operatorname{lnEI}$ & $5.613 *$ \\
\hline $\operatorname{lnREC}$ & $\operatorname{lnCPI}$ & $6.403 * * *$ & $\operatorname{lnRES}$ & $\operatorname{lnCPI}$ & 10.263 & $\ln E I$ & $\operatorname{lnCPI}$ & 1.252 \\
\hline $\operatorname{lnCPI}$ & $\operatorname{lnREC}$ & 1.049 & $\operatorname{lnCPI}$ & $\operatorname{lnRES}$ & $5.882 *$ & $\operatorname{lnCPI}$ & $\operatorname{lnEI}$ & 0.672 \\
\hline
\end{tabular}

The estimated $\mathrm{Chi}^{2}$-statistics are reported; ***,**, and *Statistical significance at $1 \%, 5 \%$, and $10 \%$ levels respectively 
Table 11 Panel Granger causality test results

\begin{tabular}{|c|c|c|c|c|c|}
\hline \multicolumn{3}{|l|}{ Model (4) } & \multicolumn{3}{|c|}{ Model (5) \& (6) } \\
\hline $\begin{array}{l}\text { Dep. } \\
\text { var. }\end{array}$ & $\begin{array}{l}\text { Indep. } \\
\text { var. }\end{array}$ & $\mathrm{Chi}^{2}$-stat & $\begin{array}{l}\text { Dep. } \\
\text { var. }\end{array}$ & $\begin{array}{l}\text { Indep. } \\
\text { var. }\end{array}$ & $\begin{array}{l}\mathrm{Chi}^{2}- \\
\text { stat }\end{array}$ \\
\hline $\ln \mathrm{ACFT}$ & lnIOPEN & 1.966 & $\operatorname{lnCO} \mathrm{C}_{2}$ & lnIOPEN & $6.224 * *$ \\
\hline lnIOPEN & $\ln \mathrm{ACFT}$ & 2.196 & lnIOPEN & $\operatorname{lnCO} 2$ & 2.123 \\
\hline $\ln \mathrm{ACFT}$ & $\operatorname{lnCO} \mathrm{C}_{2}$ & 4.111 & $\operatorname{lnCO}{ }_{2}$ & $\ln R E C$ & 2.675 \\
\hline $\operatorname{lnCO} 2$ & $\ln \mathrm{ACFT}$ & 3.110 & $\ln R E C$ & $\operatorname{lnCO} 2$ & 1.443 \\
\hline $\ln \mathrm{ACFT}$ & $\operatorname{lnOIL}$ & $7.472 * *$ & $\operatorname{lnCO} \mathrm{C}_{2}$ & lnNREC & 3.232 \\
\hline $\operatorname{lnOIL}$ & $\ln \mathrm{ACFT}$ & 0.219 & lnNREC & $\operatorname{lnCO} 2$ & 1.160 \\
\hline $\ln \mathrm{ACFT}$ & $\operatorname{lnLIFE}$ & $5.372 *$ & $\operatorname{lnCO} \mathrm{CO}_{2}$ & $\ln E I$ & 2.423 \\
\hline $\operatorname{lnLIFE}$ & $\ln \mathrm{ACFT}$ & $33.258 * * *$ & $\ln E I$ & $\operatorname{lnCO} 2$ & 1.923 \\
\hline $\ln \mathrm{ACFT}$ & $\operatorname{lnSSE}$ & $5.398^{*}$ & $\operatorname{lnCO} 2$ & $\ln \mathrm{ACFT}$ & 1.112 \\
\hline $\operatorname{lnSSE}$ & $\ln \mathrm{ACFT}$ & 1.167 & $\ln \mathrm{ACFT}$ & $\operatorname{lnCO} 2$ & 1.369 \\
\hline $\operatorname{lnACFT}$ & $\operatorname{lnCPI}$ & 0.541 & $\operatorname{lnCO} 2$ & $\operatorname{lnOIL}$ & $5.269 *$ \\
\hline $\operatorname{lnCPI}$ & $\ln \mathrm{ACFT}$ & $4.998^{*}$ & $\operatorname{lnOIL}$ & $\operatorname{lnCO} 2$ & 1.036 \\
\hline $\operatorname{lnACFT}$ & lnGNIPC & 2.589 & $\operatorname{lnCO} 2$ & lnGNIPC & 0.914 \\
\hline lnGNIPC & $\ln \mathrm{ACFT}$ & $9.307 * * *$ & lnGNIPC & $\operatorname{lnCO} 2$ & $5.103 *$ \\
\hline
\end{tabular}

The estimated $\mathrm{Chi}^{2}$-statistics are reported; ***, **, and *Statistical significance at $1 \%, 5 \%$, and $10 \%$ levels respectively
Table 13 Geweke's (1982) measure of instantaneous feedback results

Model (4) Models (5) and (6)

\begin{tabular}{|c|c|c|c|}
\hline Null hypothesis ${ }^{\mathrm{a}}$ & $\mathrm{Chi}^{2}$ stat. & Null hypothesis ${ }^{\mathrm{a}}$ & $\mathrm{Chi}^{2}$ stat. \\
\hline $\ln \mathrm{ACFT}$ and $\operatorname{lnIOPEN}$ & 0.944 & $\operatorname{lnCO} \mathrm{C}_{2}$ and $\operatorname{lnIOPEN}$ & 1.229 \\
\hline $\ln \mathrm{ACFT}$ and $\ln \mathrm{CO}_{2}$ & 0.002 & $\operatorname{lnCO} \mathrm{C}_{2}$ and $\ln \mathrm{REC}$ & 2.037 \\
\hline $\ln A C F T$ and $\ln \mathrm{OIL}$ & 1.834 & $\operatorname{lnCO} \mathrm{O}_{2}$ and $\operatorname{lnNREC}$ & $3.670 *$ \\
\hline $\ln A C F T$ and $\operatorname{lnLIFE}$ & $6.835 * * *$ & $\operatorname{lnCO} \mathrm{C}_{2}$ and $\ln \mathrm{EI}$ & 2.299 \\
\hline $\ln A C F T$ and $\operatorname{lnSSE}$ & 1.440 & $\operatorname{lnCO} \mathrm{O}_{2}$ and $\ln \mathrm{ACFT}$ & 2.114 \\
\hline $\ln A C F T$ and $\operatorname{lnGNIPC}$ & 0.188 & $\operatorname{lnCO} \mathrm{C}_{2}$ and $\ln \mathrm{OIL}$ & $5.166 * *$ \\
\hline $\ln A C F T$ and $\operatorname{lnCPI}$ & 1.433 & $\operatorname{lnCO}{ }_{2}$ and $\ln \mathrm{GNIPC}$ & $5.273 * *$ \\
\hline
\end{tabular}

a The null hypothesis of the presence of instantaneous feedback; ***,**, and $*$ Statistical significance at $1 \%, 5 \%$, and $10 \%$ levels respectively
Table 12 Geweke's (1982) measure of instantaneous feedback results

\begin{tabular}{|c|c|c|c|c|c|}
\hline \multicolumn{2}{|l|}{ Model (1) } & \multicolumn{2}{|l|}{ Model (2) } & \multicolumn{2}{|l|}{ Model (3) } \\
\hline Null hypothesis ${ }^{\mathrm{a}}$ & $\mathrm{Chi}^{2}$ stat. & Null hypothesis ${ }^{\mathrm{a}}$ & $\mathrm{Chi}^{2}$ stat. & Null hypothesis ${ }^{\mathrm{a}}$ & $\mathrm{Chi}^{2}$ stat. \\
\hline lnREC and lnIOPEN & 0.425 & lnRES and $\operatorname{lnIOPEN}$ & 0.946 & $\operatorname{lnEI}$ and $\operatorname{lnIOPEN}$ & 2.177 \\
\hline $\operatorname{lnREC}$ and $\operatorname{lnCO} \mathrm{C}_{2}$ & 1.168 & $\operatorname{lnRES}$ and $\operatorname{lnCO}{ }_{2}$ & $1.240 * * *$ & $\operatorname{lnEI}$ and $\operatorname{lnCO} 2$ & 0.364 \\
\hline $\operatorname{lnREC}$ and $\operatorname{lnOIL}$ & 0.306 & $\operatorname{lnRES}$ and $\operatorname{lnOIL}$ & 0.025 & $\operatorname{lnEI}$ and $\operatorname{lnOIL}$ & $16.125 * * *$ \\
\hline $\operatorname{lnREC}$ and $\operatorname{lnFDI}$ & 0.312 & $\operatorname{lnRES}$ and $\operatorname{lnFDI}$ & $7.714 * * *$ & $\operatorname{lnEI}$ and $\operatorname{lnFDI}$ & 0.002 \\
\hline $\operatorname{lnREC}$ and $\operatorname{lnREMIT}$ & 0.266 & $\operatorname{lnRES}$ and $\operatorname{lnREMIT}$ & 0.015 & $\operatorname{lnEI}$ and $\operatorname{lnREMIT}$ & 0.815 \\
\hline $\operatorname{lnREC}$ and $\operatorname{lnNODA}$ & 0.130 & $\operatorname{lnRES}$ and $\operatorname{lnNODA}$ & $2.564^{*}$ & $\operatorname{lnEI}$ and $\operatorname{lnNODA}$ & 0.953 \\
\hline $\operatorname{lnREC}$ and $\operatorname{lnGNIPC}$ & $3.531 *$ & $\ln R E S$ and $\operatorname{lnGNIPC}$ & 0.176 & $\operatorname{lnEI}$ and $\operatorname{lnGNIPC}$ & 2.013 \\
\hline $\operatorname{lnREC}$ and $\operatorname{lnCPI}$ & 0.004 & $\operatorname{lnRES}$ and $\operatorname{lnCPI}$ & 1.134 & $\operatorname{lnEI}$ and $\operatorname{lnCPI}$ & 4.132 \\
\hline
\end{tabular}

${ }^{a}$ The null hypothesis of the presence of instantaneous feedback; ***, **, and *Statistical significance at $1 \%, 5 \%$, and $10 \%$ levels respectively 


\section{References}

Abid MR, Lghoul R, Benhaddou D (2017). ICT for renewable energy integration into smart buildings: IoT and big data approach. In 2017 IEEE AFRICON (pp. 856-861). IEEE.

Acharya B, Marhold K (2019) Determinants of household energy use and fuel switching behavior in Nepal. Energy 169:1132-1138

Acharya V, Hegde VV, Anjan K, Kumar M (2017). IoT (Internet of Things) based efficiency monitoring system for bio-gas plants. In 2017 2nd International Conference on Computational Systems and Information Technology for Sustainable Solution (CSITSS) (pp. 15). IEEE.

Afridi MA, Kehelwalatenna S, Naseem I, Tahir M (2019) Per capita income, trade openness, urbanization, energy consumption, and CO 2 emissions: an empirical study on the SAARC Region. Environ Sci Pollut Res 26(29):29978-29990

Agrawala S, Raksakulthai V, van Aalst M, Larsen P, Smith J, Reynolds J (2003) Development and climate change in Nepal: focus on water resources and hydropower (pp. 14-28). Paris: OECD.

Ahmed F, Naeem M, Iqbal M (2017) ICT and renewable energy: a way forward to the next generation telecom base stations. Telecommun Syst 64(1):43-56

Ajayi OO, Ohijeagbon OD (2017) Feasibility and techno-economic assessment of stand-alone and hybrid RE for rural electrification in selected sites of south eastern Nigeria. International Journal of Ambient Energy 38(1):55-68

Alstone P, Gershenson D, Kammen DM (2015) Decentralized energy systems for clean electricity access. Nat Clim Chang 5(4):305-314

Amri F, Zaied YB, Lahouel BB (2019) ICT, total factor productivity, and carbon dioxide emissions in Tunisia. Technol Forecast Soc Chang $146: 212-217$

Andreopoulou Z (2012) Green Informatics: ICT for green and sustainability. Agrárinformatika/Journal of Agricultural Informatics 3(2): $1-8$

Apergis N (2016) Environmental Kuznets curves: New evidence on both panel and country-level CO2 emissions. Energy Econ 54:263-271

Apergis E, Apergis N (2017) The role of rare earth prices in renewable energy consumption: the actual driver for a renewable energy world. Energy Econ 62:33-42

Apergis N, Ozturk I (2015) Testing environmental Kuznets curve hypothesis in Asian countries. Ecol Indic 52:16-22

Apergis N, Payne JE (2015) Renewable energy, output, carbon dioxide emissions, and oil prices: evidence from South America. Energy Sources, Part B: Economics, Planning, and Policy 10(3):281-287

Arnone D, Bertoncini M, Rossi A, D'Errico F, García-Santiago C, Moneta D, D'Orinzi C (2013). An ICT-based energy management system to integrate renewable energy and storage for grid balancing. In Proceedings of the fourth international conference on Future energy systems (pp. 259-260)

Asongu SA (2018) ICT, openness and CO 2 emissions in Africa. Environ Sci Pollut Res 25(10):9351-9359

Asongu SA, Le Roux S, Biekpe N (2018) Enhancing ICT for environmental sustainability in sub-Saharan Africa. Technol Forecast Soc Chang 127:209-216

Avom D, Nkengfack H, Fotio HK, Totouom A (2020) ICT and environmental quality in Sub-Saharan Africa: Effects and transmission channels. Technol Forecast Soc Chang 155:120028

Bai J, Kao C, Ng S (2009) Panel cointegration with global stochastic trends. J Econ 149(1):82-99

Baltagi B (2008) Econometric analysis of panel data. John Wiley \& Sons

Baltagi BH (2013) Econometric analysis of panel data. John Wiley \& Sons Inc, Hoboken

Barıș-Tüzemen Ö, Tüzemen S, Çelik AK (2020) Does an N-shaped association exist between pollution and ICT in Turkey? ARDL and quantile regression approaches. Environmental Science and Pollution Research, 1-14.

Bastida L, Cohen JJ, Kollmann A, Moya A, Reichl J (2019) Exploring the role of ICT on household behavioural energy efficiency to mitigate global warming. Renew Sust Energ Rev 103:455-462

Bernstein R, Madlener R (2010) Impact of disaggregated ICT capital on electricity intensity in European manufacturing. Appl Econ Lett 17(17):1691-1695

Bessa R, Moreira C, Silva B, Matos M (2014) Handling renewable energy variability and uncertainty in power systems operation. Wiley Interdisciplinary Reviews: Energy and Environment 3(2):156-178

BP (2019) Statistical Review of World Energy. British Petroleum, London

Breusch TS, Pagan AR (1980) The Lagrange multiplier test and its applications to model specification in econometrics. Rev Econ Stud 47(1):239-253

Cho Y, Lee J, Kim TY (2007) The impact of ICT investment and energy price on industrial electricity demand: Dynamic growth model approach. Energy Policy 35(9):4730-4738

Cole MA (2004) Trade, the pollution haven hypothesis and the environmental Kuznets curve: examining the linkages. Ecol Econ 48(1):7181

Collard F, Fève P, Portier F (2005) Electricity consumption and ICT in the French service sector. Energy Econ 27(3):541-550

Da Silva PG, Ilić D, Karnouskos S (2013) The impact of smart grid prosumer grouping on forecasting accuracy and its benefits for local electricity market trading. IEEE Transactions on Smart Grid 5(1): 402-410

Dhiman B, Chaudhury MK, Mahapatra S, Chakrabarti D (2019) Socially constructed design in context of small-scale solar photovoltaic home system. In Research into Design for a Connected World (pp. 391401). Springer, Singapore.

Doukas H, Marinakis V, Tsapelas J, Sgouridis S (2019) Intelligent energy management within the smart cities: an EU-GCC cooperation opportunity. In Smart Cities in the Gulf (pp. 123-147). Palgrave Macmillan, Singapore.

Droege P (2011) Urban energy transition: from fossil fuels to renewable power. Elsevier.

Dumitrescu EI, Hurlin C (2012) Testing for Granger non-causality in heterogeneous panels. Econ Model 29(4):1450-1460

Edomah N (2016) On the path to sustainability: Key issues on Nigeria's sustainable energy development. Energy Rep 2:28-34

Ekström R, Kurupath V, Svensson O, Leijon M (2013) Measurement system design and implementation for grid-connected marine substation. Renew Energy 55:338-346

Erdogan S, Okumus I, Guzel AE (2020) Revisiting the environmental Kuznets curve hypothesis in OECD countries: the role of renewable, non-renewable energy, and oil prices. Environ Sci Pollut Res:1-9

Evans W, Johnson M, Jagoe K, Charron D, Young B, Rahman ASMM et al (2017) Evaluation of behavior change communication campaigns to promote modern cookstove purchase and use in lowermiddle-income countries. Int J Environ Res Public Health 15(1):11

Fadaeenejad M, Radzi MAM, AbKadir MZA, Hizam H (2014) Assessment of hybrid renewable power sources for rural electrification in Malaysia. Renew Sust Energ Rev 30:299-305

Faisal F, Tursoy T, Pervaiz R (2020) Does ICT lessen CO 2 emissions for fast-emerging economies? An application of the heterogeneous panel estimations Environmental Science and Pollution Research:1-12

Fashina A, Mundu M, Akiyode O, Abdullah L, Sanni D, Ounyesiga L (2019) The drivers and barriers of renewable energy applications and development in Uganda: a review. Clean Technologies 1(1): 9-39

Field CB (ed) (2014) Climate change 2014-Impacts, adaptation and vulnerability: regional aspects. Cambridge University Press

Fung CC, Tang SC, Wong KP (2010, July). A proposed study on the use of ICT and smart meters to influence consumers' behavior and 
attitude towards Renewable Energy. In IEEE PES General Meeting (pp. 1-5). IEEE.

Geweke J (1982) Measurement of linear dependence and feedback between multiple time series. J Am Stat Assoc 77:304-313

Godil DI, Sharif A, Agha H, Jermsittiparsert K (2020) The dynamic nonlinear influence of ICT, financial development, and institutional quality on $\mathrm{CO} 2$ emission in Pakistan: new insights from QARDL approach. Environ Sci Pollut Res:1-11

Goebel C, Callaway DS (2012) Using ICT-controlled plug-in electric vehicles to supply grid regulation in California at different renewable integration levels. IEEE Transactions on Smart Grid 4(2):729740

Goldbach K, Rotaru AM, Reichert S, Stiff G, Gölz S (2018) Which digital energy services improve energy efficiency? A multi-criteria investigation with European experts. Energy Policy 115:239-248

Granger CWJ (1969) Investigating causal relations by econometric models and cross-spectral methods. Econometrica 37:424-438

Gujarati DN (2005) Basic Econometrics, 4th edn. McGraw-Hill, New York

Haider S, Adil M, Ganaie A (2019) Does industrialisation and urbanisation affect energy consumption: a relative study of India and Iran? Econ Bull 39(1):176-185

Hammons TJ (2008) Integrating renewable energy sources into European grids. Int J Electr Power Energy Syst 30(8):462-475

Haseeb A, Xia E, Saud S, Ahmad A, Khurshid H (2019) Does information and communication technologies improve environmental quality in the era of globalization? An empirical analysis. Environ Sci Pollut Res 26(9):8594-8608

Hatzigeorgiou E, Polatidis H, Haralambopoulos D (2011) CO2 emissions, GDP and energy intensity: a multivariate cointegration and causality analysis for Greece, 1977-2007. Appl Energy 88(4):13771385

Heckscher EF (1919) The effects of foreign trade on the distribution of income' Ekonomisk Tidskrift (1919). pp. 497-512.

Higón DA, Gholami R, Shirazi F (2017) ICT and environmental sustainability: a global perspective. Telematics Inform 34(4):85-95

Hsiao C (2005) Why panel data? Singap Econ Rev 50(2):1-12

Hsiao C (2007) Panel data analysis - advantages and challenges. Test 16(1):1-22

IEA (2017a) Perspectives for energy transition: investment needs for a lowcarbon energy ssystem. International Renewable Energy Available at: https://www.irena.org/-/media/Files/IRENA/Agency/Publication/ 2017/Mar/Perspectives_for_the_Energy_Transition_2017.pdf

IEA (2017b) Digitalisation and energy. International Energy Association. Available at: https://www.iea.org/reports/digitalisation-and-energy

IRENA (2018) Global energy transformation: a roadmap to 2050, International Renewable Energy Agency, Abu Dhabi. Retrieved from: www.irena.org/publications

Jaffar MM, Nahil MA, Williams PT (2019) Parametric study of CO2 methanation for synthetic natural gas production. Energy Technology 7(11):1900795

Karnouskos S (2011). Demand side management via prosumer interactions in a smart city energy marketplace. In 2011 2nd IEEE PES International Conference and Exhibition on Innovative Smart Grid Technologies (pp. 1-7). IEEE.

Khan N, Baloch MA, Saud S, Fatima T (2018) The effect of ICT on CO 2 emissions in emerging economies: does the level of income matters? Environ Sci Pollut Res 25(23):22850-22860

Khan ZU, Ahmad M, Khan A (2020) On the remittances-environment led hypothesis: empirical evidence from BRICS economies. Environmental Science and Pollution Research, 1-12.

Khayyat NT, Lee J, Heo E (2016) How ICT investment influences energy demand in South Korea and Japan. Energy Efficiency 9(2):563-589

Kostevšek A, Cizelj L, Petek J, Pivec A (2013) A novel concept for a renewable network within municipal energy systems. Renew Energy 60:79-87
Kumar P, Igdalsky L (2019) Sustained uptake of clean cooking practices in poor communities: role of social networks. Energy Res Soc Sci 48:189-193

Kumar A, Kumar K, Kaushik N, Sharma S, Mishra S (2010) Renewable energy in India: current status and future potentials. Renew Sust Energ Rev 14(8):2434-2442

Lai CS, Jia Y, Xu Z, Lai LL, Li X, Cao J, McCulloch MD (2017) Levelized cost of electricity for photovoltaic/biogas power plant hybrid system with electrical energy storage degradation costs. Energy Convers Manag 153:34-47

Laitner JAS (2015) The energy efficiency benefits and the economic imperative of ICT-enabled systems. In ICT Innovations for Sustainability (pp. 37-48). Springer, Cham.

Lu J, Ren L, Yao S, Rong D, Skare M, Streimikis J (2020) Renewable energy barriers and coping strategies: evidence from the Baltic States. Sustain Dev 28(1):352-367

Malmodin J, Bergmark P (2015) Exploring the effect of ICT solutions on GHG emissions in:2030. https://doi.org/10.2991/ict4s-env-15.2015.5

Marton C, Hagert M (2017) The effects of FDI on renewable energy consumption. http://lup.lub.lu.se/student-papers/record/8912090

Mathiesen BV, Lund H, Connolly D, Wenzel H, Østergaard PA, Möller B, Hvelplund FK (2015) Smart energy systems for coherent 100\% renewable energy and transport solutions. Appl Energy 145:139154

McBain B (2016) Reliable renewable electricity is possible if we make smart decisions now. The Conversation. Available at: https:// theconversation.com/reliable-renewable-electricity-is-possible-ifwe-make-smart-decisions-now-68585

Miller J, Bird L, Heeter J, Gorham B (2015) Renewable electricity use by the US information and communication technology (ICT) industry (No. NREL/TP-6A20-64011). National Renewable Energy Lab (NREL), Golden, CO (United States).

Moyer JD, Hughes BB (2012) ICTs: do they contribute to increased carbon emissions? Technol Forecast Soc Chang 79:919-931

Murshed M (2018) Does improvement in trade openness facilitate renewable energy transition? Evidence from selected South Asian economies. South Asia Economic Journal 19(2):151-170

Murshed M (2019) A review of the prospects and benefits of smart gridding technology adoption in Bangladesh's power sector. Natural Gas \& Electricity 36(3):19-28

Murshed M (2020a) Are trade liberalization policies aligned with renewable energy transition in low and middle income countries? An Instrumental Variable approach. Renew Energy 151:1110-1123

Murshed M (2020b) Electricity conservation opportunities within private university campuses in Bangladesh. Energy \& Environment 31(2): 256-274

Murshed M, Tanha MM (2020) Oil price shocks and renewable energy transition: empirical evidence from net oil-importing South Asian economies. Energy, Ecology and Environment. https://doi.org/10. 1007/s40974-020-00168-0

Nath HK, Liu L (2017) Information and communications technology (ICT) and services trade. Inf Econ Policy 41:81-87

Nguyen KH, Kakinaka M (2019) Renewable energy consumption, carbon emissions, and development stages: some evidence from panel cointegration analysis. Renew Energy 132:1049-1057

Ohlin B (1933) International and Interregional Trade. Harvard Economic Studies, Cambridge, MA

Omri A, Nguyen DK (2014) On the determinants of renewable energy consumption: international evidence. Energy 72:554-560

Ozcan B, Apergis N (2018) The impact of internet use on air pollution: evidence from emerging countries. Environ Sci Pollut Res 25(5): 4174-4189

Palit D, Bandyopadhyay KR (2016) Rural electricity access in South Asia: is grid extension the remedy? A critical review. Renew Sust Energ Rev 60:1505-1515 
Panajotovic B, Jankovic M, Odadzic B (2011) ICT and smart grid. In Proceedings for the 10th International Conference on Telecommunication in Modern Satellite Cable and Broadcasting Services (pp. 118-121).

Park Y, Meng F, Baloch MA (2018) The effect of ICT, financial development, growth, and trade openness on $\mathrm{CO} 2$ emissions: an empirical analysis. Environ Sci Pollut Res 25(30):30708-30719

Pasetti M, Rinaldi S, Manerba D (2018) A virtual power plant architecture for the demand-side management of smart prosumers. Appl Sci $8(3): 432$

Pasichnyi O, Levihn F, Shahrokni H, Wallin J, Kordas O (2019) Datadriven strategic planning of building energy retrofitting: The case of Stockholm. J Clean Prod 233:546-560

Pata UK (2018) Renewable energy consumption, urbanization, financial development, income and $\mathrm{CO} 2$ emissions in Turkey: testing EKC hypothesis with structural breaks. J Clean Prod 187:770-779

Paul DI, Uhomoibhi J (2014) Solar electricity generation: issues of development and impact on ICT implementation in Africa. CampusWide Information Systems.

Pedroni P (1999) Critical values for cointegration tests in heterogeneous panels with multiple regressors. Oxf Bull Econ Stat 61:653-670

Pesaran MH (2004) General diagnostic tests for cross section dependence in panels. Cambridge Working Paper in Economics No. 0435.

Pesaran MH (2007) A simple panel unit root test in the presence of crosssection dependence. J Appl Econ 22(2):265-312

Raheem ID, Tiwari AK, Balsalobre-Lorente D (2020) The role of ICT and financial development in $\mathrm{CO} 2$ emissions and economic growth. Environ Sci Pollut Res 27(2):1912-1922

Rockström J, Gaffney O, Rogelj J, Meinshausen M, Nakicenovic N, Schellnhuber HJ (2017) A roadmap for rapid decarbonization. Science 355(6331):1269-1271

Rodríguez Casal C, Van Wunnik C, Delgado Sancho L, Claude Burgelman J, Desruelle P (2005) How will ICTs affect our environment in 2020? Foresight 7(1):77-87. https://doi.org/10.1108/ 14636680510581330

Røpke I, Christensen TH (2012) Energy impacts of ICT-Insights from an everyday life perspective. Telematics Inform 29(4):348-361

Saboori B, Sulaiman J (2013) Environmental degradation, economic growth and energy consumption: evidence of the environmental Kuznets curve in Malaysia. Energy Policy 60:892-905

Sadorsky P (2012) Information communication technology and electricity consumption in emerging economies. Energy Policy 48:130-136

Samargandi N (2019) Energy intensity and its determinants in OPEC countries. Energy 186:115803

Schulte P, Welsch H, Rexhäuser S (2016) ICT and the demand for energy: evidence from OECD countries. Environ Resour Econ 63(1): $119-146$

Schunder T, Bagchi-Sen S (2019) Understanding the household cooking fuel transition. Geogr Compass 13(11):e12469

Shafiei S, Salim RA (2014) Non-renewable and renewable energy consumption and $\mathrm{CO} 2$ emissions in OECD countries: a comparative analysis. Energy Policy 66:547-556

Shahnazi R, Shabani ZD (2019) The effects of spatial spillover information and communications technology on carbon dioxide emissions in Iran. Environ Sci Pollut Res 26(23):24198-24212

Sharif A, Mishra S, Sinha A, Jiao Z, Shahbaz M, Afshan S (2020) The renewable energy consumption-environmental degradation nexus in Top-10 polluted countries: fresh insights from quantile-on-quantile regression approach. Renew Energy

Smil V, Knowland WE (1980) Energy in the developing world: the real energy crisis.

Suryawanshi K, Narkhede S (2020) Green ICT in higher Education: the next frontier for sustainable growth. Know Your CSI, 12.

Tsivor KK (2011, October) Renewable energy (green ICT) support for mobile communications in Africa. In 2011 IEEE 33rd International Telecommunications Energy Conference (INTELEC) (pp. 1-6). IEEE.
Tsurumi T, Managi S (2010) Decomposition of the environmental Kuznets curve: scale, technique, and composition effects. Environ Econ Policy Stud 11(1-4):19-36

Uhomoibhi J, Paul DI (2012) Solar power generation for ICT and sustainable development in emerging economies. Campus-Wide Information Systems.

UNCTAD (2019) The role of science, technology and innovation in promoting renewable energy by 2030 . The United Nations Conference on Trade and Development. Retrieved from: https:// unctad.org/en/PublicationsLibrary/dtlstict2019d2 en.pdf

UNEP and WMO (2011) Integrated assessment of black carbon and tropospheric ozone: summary for decision makers. United Nations Environmental Programme and World Meteorological Organization, Nairobi

van Alphen K, van Sark WG, Hekkert MP (2007) Renewable energy technologies in the Maldives - determining the potential. Renew Sust Energ Rev 11(8):1650-1674

Vanek J (1968) The factor proportions theory: the $\mathrm{n}$-factor case. Kyklos 21(4):749-756

Vergados DJ, Mamounakis I, Makris P, Varvarigos E (2016) Prosumer clustering into virtual microgrids for cost reduction in renewable energy trading markets. Sustainable Energy, Grids and Networks 7:90-103

Voigt S, De Cian E, Schymura M, Verdolini E (2014) Energy intensity developments in 40 major economies: structural change or technology improvement? Energy Econ 41:47-62

Walzberg J, Dandres T, Merveille N, Cheriet M, Samson R (2020) Should we fear the rebound effect in smart homes? Renew Sust Energ Rev 125:109798

Wang D, Han B (2016) The impact of ICT investment on energy intensity across different regions of China. Journal of Renewable and Sustainable Energy 8(5):055901

Weiller C, Neely A (2014) Using electric vehicles for energy services: Industry perspectives. Energy 77:194-200

Westerlund J (2007) Testing for error correction in panel data. Oxf Bull Econ Stat 69(6):709-748

WHO (2012) Health effects of black carbon. World Health Organization, Copenhagen

World Bank (2020) World Development Indicators database. The World Bank.

World Energy Council (2018) The role of ICT in energy efficiency management: Household Sector. Available at https://www.worldenergy. org/wp-content/uploads/2018/06/20180420_TF_paper_final.pdf

Xue Y, Cai B, James G, Dong Z, Wen F, Xue F (2014) Primary energy congestion of power systems. Journal of Modern Power Systems and Clean Energy 2(1):39-49

Yan Z, Shi R, Yang Z (2018) ICT Development and sustainable energy consumption: a perspective of Energy Productivity. Sustainability 10(7):2568

Yang M, Yu X (2015) Energy efficiency: benefits for environment and society. Springer.

Yasmin N, Grundmann P (2019) Adoption and diffusion of renewable energy-the case of biogas as alternative fuel for cooking in Pakistan. Renew Sust Energ Rev 101:255-264

Zeren F, Akkuș HT (2020) The relationship between renewable energy consumption and trade openness: new evidence from emerging economies. Renew Energy 147:322-329

Zhang C, Liu C (2015) The impact of ICT industry on CO2 emissions: a regional analysis in China. Renew Sust Energ Rev 44:12-19

Zhou X, Zhou D, Wang Q (2018) How does information and communication technology affect China's energy intensity? A three-tier structural decomposition analysis. Energy 151:748-759

Publisher's note Springer Nature remains neutral with regard to jurisdictional claims in published maps and institutional affiliations. 